\title{
EL PROCESO DE SOCIALIZACIÓN \\ DE LOS ADOLESCENTES: ENTRE LA INCLUSIÓN Y EL RIESGO. RECOMENDACIONES PARA UNA CIUDADANÍA SOSTENIBLE
}

\author{
THE PROCESS OF SOCIALIZATION \\ IN TEENAGERS: BETWEEN THE INTEGRATION AND THE RISK. \\ GUIDELINES FOR A SUSTAINABLE CITIZENSHIP1
}

\author{
O PROCESSO DE SOCIALIZAÇÃO \\ EM ADOLESCENTES: ENTRE A INTEGRAÇÃO EO RISCO. \\ DIRETRIZES PARA UMA CIDADANIA SUSTENTÁVEL
}

José-Javier Navarro-Pérez y José-Vicente Pérez-Cosín

UNIVERSIDAD DE VALENCIA

Silvia Perpiñán

University OF Western Ontario (CANAdÁ)

RESUMEN: El presente artículo refleja los intereses, opiniones e incertidumbres que envuelven a adolescentes residentes en entornos de fragilidad. Es un estudio que aborda estas circunstancias desde tres barrios del área metropolitana de Valencia. Se analiza el entorno en que socializan: sus relaciones familiares y comunitarias, sus hábitos y percepciones de la realidad sobre la que actúan. Centramos nuestra mirada en ellos y ellas, con la finalidad de identificar sus riesgos y establecer un diagnóstico que nos permita determinar los hándicaps que surgen en sus procesos de socialización. Desarrollamos una metodología de triangulación cuantitativa y cualitativa en función de los objetivos que hemos diseñado. Todo ello con intención de elaborar líneas estratégicas orientadas a la inclusión socioeducativa. Así, se toma la actual transformación de las estructuras sociales como eje estructural y en base a ello, los principales factores positivos y negativos que inciden en una socialización resistente o por el contrario sometida a riesgos.

Los principales hallazgos que nos deja la presente investigación contemplan una alteración de las estructuras sociales que inciden en el sometimiento del adolescente hacia el consumo; ello incide en la pérdida gradual de actividades lúdicas grupales, con exiguas referencias a la vida y recursos comunitarios, una cosificación del juego con escaso margen para la creatividad, etc. Se observa cierta subversión del sistema de valores y desinterés en las administraciones sociales y educativas para la planificación y gestión de los tiempos de ocio. Se propone que las instituciones públicas locales lideren la creación de mecanismos generadores de una conciencia crítica, que colabore en el aprendizaje activo de los adolescentes. 
PALABRAS CLAVE: Trabajo Social; Adolescencia; Socialización; Riesgos; Sostenibilidad.

ABSTRACT: The present study portraits the interests, opinions, and uncertainties that surround teenagers who live in a fragile environment. This study addresses these situations in three neighborhoods of the metropolitan area of Valencia. It analyzes the context in which these teenagers socialize: their family ties and community relationships, their routines and reality perceptions. We focus on these teenagers with the aim of identifying the risks they are exposed to, and proposing a diagnosis that determines the challenges these teenagers find when socializing. We employ triangulation to analyze quantitative and qualitative data. The ultimate purpose of this study is to develop guidelines for the socio-educational inclusion. Reamed within the new social change studies, this paper analyzes the main positive and negative factors that have an impact on a resilient socialization or, on the contrary, on a risky socialization.

The main results show a change in the society which mainly affects adolescents. Little interest in group recreational activities, with few references to life in the community, loss of imagination in games. There are few references to the value system, little interest in government to plan leisure. It is proposed that local government institutions build critical awareness mechanisms to work in active learning of adolescents.

KEYWORDS: Social Work; Adolescence; Socialization; Risks; Sustainability.

RESUMO: O presente estudo retrata os interesses, opiniões e incertezas que cercam os adolescentes que vivem em um ambiente frágil. Este estudo aborda estas situações em três bairros da região metropolitana de Valência. Análise o contexto em que esses adolescentes socializar: seus laços familiares e relações com a comunidade, suas rotinas e realidade percepções. Nós nos concentramos nesses adolescentes com o objetivo de identificar os riscos a que estão expostos, e propor um diagnóstico que determina os desafios que esses adolescentes encontram quando socializar. Nós empregamos triangulação para analisar os dados quantitativos e qualitativos. $O$ objetivo final deste estudo é desenvolver diretrizes para a inclusão sócioeducativa. Integrado dentro dos novos estudos de mudança social, o presente trabalho analisa os principais fatores positivos e negativos que têm um impacto sobre a socialização resiliente ou, pelo contrário, em uma socialização arriscado. Os principais resultados mostram uma mudança na sociedade que afeta principalmente adolescentes. Muito pouco interesse em atividades de lazer organizadas, com pouca referência à vida da comunidade e imaginação para criar jogo reduzida. Há poucas referências ao sistema de valores, pouco interesse no governo para planejar o lazer. Propõe-se que as instituições governamentais locais a construir mecanismos críticos de conscientização para trabalhar na aprendizagem ativa de adolescentes.

PALAVRAS-CHAVE: Serviço Social; Adolescência; Socialização; Riscos; Sustentabilidade.

[ 144 ] JOSÉ-JAVIER NAVARRO-PÉREZ, JOSÉ-VICENTE PÉREZ-COSÍN Y SILVIA PERPIÑÁN SIPS - PEDAGOGIA SOCIAL. REVISTA INTERUNIVERSITARIA [1139-1723 (2015) 25, 143-170] TERCERA ÉPOCA 


\section{Introducción: el proceso de socialización y los espacios cotidianos como punto de partida}

Para aproximarnos a la realidad que viven los adolescentes vinculados de alguna manera a entornos de riesgo, consideramos primordial analizar las relaciones familiares, las expectativas, las redes de socialización, el papel de la formación obligatoria y reglada, la estructura de ocio y tiempo libre del que disfrutan, las pautas de recreo, los canales de sociabilidad y los consumos. Un amplio abanico de circunstancias que rodean la cotidianeidad de los adolescentes (Navarro \& Puig, 2010) y que encadenadas entre sí pueden producir tanto prácticas saludables como de riesgo.

El proceso de socialización emerge como piedra angular a la hora de observar, comprender, interpretar, diagnosticar, intervenir y evaluar cualquier tipo de acercamiento afectivo con los adolescentes. Definimos la socialización como argumento de vital importancia ya que según Funes (2009) se concibe como la agrupación interaccionada de mecanismos mediante los cuales un sujeto pasa a formar parte de un grupo, asumiendo los códigos, caracteres y pautas de comportamiento de éste.

Para autores como Garrido, Stangeland y Redondo (1999), el adolescente que durante el proceso de socialización coquetea con las circunstancias adversas y el riesgo posee pobres habilidades de interrelación y de resolución de problemas. Incluso otros investigadores como Rivière (2002) o Feixa (2011) proyectan que el nivel cultural afecta a la madurez emocional, la rigidez cognitiva o el pensamiento abstracto. Por el contrario, atendiendo a estímulos externos, estos adolescentes se muestran más despiertos de manera innata, ya que en ocasiones "la necesidad hace al hombre" y presentan una serie de características personales mucho más desarrolladas que las personas de su edad, como pueden ser sus habilidades para posicionarse ante las adversidades o su adaptabilidad a diferentes contextos informales (Steinberg, 2003).

Seguidamente vamos a repasar brevemente estos agentes de socialización que tendrán una incidencia directa en el desarrollo de la personalidad del adolescente.

\section{Introduction: the socialization process and the daily spaces as a starting point.}

In order to approach the reality that teenagers, related in a certain way to risky environments live, we consider essential to analyze family relations, expectations, socialization networks, the role of formal education, the structure of leisure and free time they have, break time rules and the different ways of sociability and consumption. A wide range of circumstances that surround the teenagers' daily routine (Navarro \& Puig, 2010) and linked between them can lead to healthy or risky practices.

The socialization process emerges as a cornerstone when we observe, understand, interpret, diagnose, interfere and evaluate any kind of affective approach with adolescents. We define socialization as an essential argument considering that according to Funes (2009) it is considered as an association in which their members interact and become a part of a group, assuming codes, roles and guidelines.

For authors like Garrido, Stangeland and Redondo (1999), the adolescent that during the socialization process flirts with unfavorable and risky circumstances, has poor interrelation and conflict solving abilities. Even researchers as Rivière (2002) or Feixa (2011) project that; the cultural level affects the emotional maturity, cognitive rigidity or the abstract thinking. By contrast, in response to external stimuli, these adolescents are naturally smarter, because sometimes "necessity makes men" and have a number of personal characteristics much more developed than those of their age, as for example their abilities or attitude when facing adversities or their adaptability to different informal contexts (Steinberg, 2003).

Straightaway, we will briefly review those socialization agents that will have a direct impact on the personality development of the adolescent. 


\section{La familia}

Este primer agente constituye el eje transversal sobre el que giran los primeros años de vida del niño, que actuará como una esponja capaz de integrar y asimilar diferentes conceptos. La mayoría de los investigadores, coinciden en asegurar que es la dinámica de sus círculos familiares la que condiciona en positivo o negativo la naturalidad del niño; sus actitudes y comportamientos [Vilar (1985), Bohder (1987), Alberdi (1999) y Gil Calvo (2004 y 2008)]. Desde estos argumentos consideramos relevante la función de la familia y su entorno como uno de los actores influyentes en la conducta y en el desarrollo positivo o negativo del adolescente.

La familia no es homogénea (Dempsey \& Lescott, 2013) y en este sentido, las relaciones que se intercambian y los valores que en ella se engendran repercutirán notablemente en las dinámicas de los sujetos que la conforman. Así, "la familia es la mejor trasmisora de valores y contravalores vigentes en la sociedad; integra, marca, sella y estigmatiza en el mundo de sus pautas culturales y normas de conducta a los recién nacidos por el mero hecho de nacer o estar en su seno" (Ruiz, 2009: 87). Por tanto, hay una serie de rasgos destacados que describen la importancia de la estructura familiar en el proceso de socialización del adolescente.

\section{La escuela}

La escuela tiene como objetivo la satisfacción de necesidades sociales concretas pero además "constituye un escenario sobre el que los adolescentes pueden acrecentar sus frustraciones a partir de los riesgos inherentes a su propio estilo de aprendizaje" (Lucchini, 1999: 96).

La escuela impone a sus alumnos un modo de ser y de actuar, una moralidad y unos valores. Por consiguiente, su función principal será la de educar no sólo en la versión académica del concepto sino también moral, social y normativa de los escolares. En consonancia, necesita de la coordinación de diferentes instituciones sociales. Es decir, atendiendo a las palabras de Tonucci (2007: 12), "la escuela no puede caminar sola", pues requiere del apoyo instrumental para su progreso tanto de las familias, de las políticas y de los preceptos legales que han de apuntalar este desarrollo.

\section{Family}

This first agent constitutes the transverse axis in which the early life of a child will revolve, who will act as an sponge capable of integrating and absorbing different concepts. Most of the researchers, agree that it is the dynamic of its familiar circles the one that determines positively or negatively the child's naturalness, attitude and behavior [Vilar (1985), Bohder (1987), Alberdi (1999) and Gil Calvo (2004 \& 2008)]. From these arguments we consider the role of the family and its environment as one of the influential factors in behavior and positive or negative development of the adolescence.

The family is not homogeneous (Dempsey and Lescott, 2013) and in this sense, those relationships that are exchanged and the values that in it are produced, will affect considerably the dynamics of the group members. Thus, "the family is the best value and exchange value transmitter which are valid for society; integrates, marks, seals and stigmatizes in the world of its cultural and behavior rules of the newborns just because they are born or are accepted as one of their own" (Ruiz, 2009: 87). Therefore, there is a series of highlighted features that describe the importance of family structure on the adolescent socialization process

\section{School}

The school has as its objective to satisfy specific social needs but it also "constitutes a stage in which adolescents can increase their frustrations from the inherent risks in their own learning style" (Lucchini, 1999: 96).

The school requires the students a style, a way of acting, a morality and some values. Therefore, its main purpose will be to educate not only the academic version of the concept, but also moral, social and school regulations. Accordingly, requires the coordination of different social institutions. That is, based on the words of Tonucci (2007: 12), "the school cannot walk alone", it requires instrumental support for the progress of families, politics and legal precepts that have to underpin this development.

The school needs to feel full, and this is maybe the formula that requires the chanching times. In this

[ 146 ] JOSÉ-JAVIER NAVARRO-PÉREZ, JOSÉ-VICENTE PÉREZ-COSÍN Y SILVIA PERPIÑÁN SIPS - PEDAGOGIA SOCIAL. REVISTA INTERUNIVERSITARIA [1139-1723 (2015) 25, 143-170] TERCERA ÉPOCA 
La escuela necesita sentirse plena, y quizá esta es la fórmula que requiere el intercambio de los nuevos tiempos. En este sentido, la participación actúa de garante para la transformación y la inversión cultural en el espacio local.

Los entornos educativos contaminados generan en el adolescente angustia, frustración, dificultan el aprendizaje y su socialización. A pesar de que la escuela, configura el eje de normalización para el adiestramiento en tiempos y actividades prosociales, también, en ausencia de supervisión, puede convertirse en un icono para el desarrollo de una sociabilidad inadaptada que soporta riesgos (Caride, Lorenzo \& Rodríguez, 2012). A este respecto, Cohen (1985) plantea que el escaso rendimiento de determinados niños está generado por docentes desmotivados en fijar su atención en aquellos que más lo necesitaban. Estas actitudes dejan a la intemperie determinadas pautas educativas manifestadas en mayor grado, por estudiantes de origen cultural bajo.

Desde otra perspectiva, coincidimos con Hutchinson y Robertson (2012: 127) al definir el contexto escolar y las actividades que en él se realizan como un "medio probado para mejorar la alfabetización en ocio e incrementar los conocimientos, habilidades y confianza que se necesitan para darle un significado personal, que cultive el bienestar y calidad de vida" de los adolescentes. La escuela debe impulsar el crecimiento en un ambiente positivo, gradual y heterogéneo, claves para un desarrollo vital rico en experiencias de convivencia y satisfacción.

\section{La red social}

EL grupo de pares se conforma principalmente en el periodo establecido entre la adolescencia y la madurez, a través de la sociabilidad, en torno a amigos de la escuela, del vecindario, del barrio o procedentes de actividades extracurriculares o de ocio. Así, los tiempos para la actividad relacional son catalizadores tanto de la conducta prosocial como de la inadaptación (Scandroglio \& López, 2012).

En el grupo de iguales, los jóvenes adquieren cierta independencia personal y afinidad con otros adolescentes ajenos a su entorno de control y supervisión, factor clave para aprender a establecer sus propias relaciones sociales y para formarse una sense, participation is a guaranty for transformation and cultural investment in the local space.

The corrupted educational environment, creates in the adolescent anguish, frustration, complicates their learning and socialization. Despite the school, sets the axis of standarization for training in time and pro-social activities, it also, when lacking supervision, it can become an icon for the development of a social misfit that bears risks (Caride, Lorenzo \& Rodríguez, 2012). In this regard, Cohen (1985) argues that the limited capacity of some children is generated by demotivated teachers trying to fix heir attention on those most in need. These attitudes exhibit certain educational standards highly expressed by students with a poor cultural background.

From another perspective, we agree with Hutchinson and Robertson (2012: 127) when defyning the school context and its activities as a "proven mean to improve literacy in leisure and increase knowledge, abilities and confidence needed to give personal meaning, that can develop wellbeing and quality of life" of the adolescents. The school should boost growth in a positive, gradual and heterogeneous environment, vital keys to a life development full of coexistent and satisfactory experiences.

\section{The social network}

The group of pairs is formed principally between the adolescence and maturity, through sociability, the school friends environment, the neighborhood or extracurricular or leisure activities. Thus, time for relational activities is the catalyst of pro-social behavior and maladjustment (Scandroglio \& López, 2012).

In the equals group, adolescents acquire some personal independence and affinities with other adolescents unconnected to their controlled and supervised environment, a key factor in learning to stablish their own social relations and to create an image of themselves different from the one they re- 
imagen de sí mismos distinta de la que reciben a través de sus padres o profesores (Ovejero, Moral \& Pastor, 1998).

Una cuestión sustancial relacionada con los grupos de iguales es su operatividad, es decir, su capacidad de posicionamiento tanto en el territorio físico y en conexión directa con los riesgos (Uceda, Pitarch \& Montón, 2012) o por el contrario virtual, estableciendo una relación abstracta. Además, dentro de estos grupos se genera lo que Cieslick y Pollock (2002) identifican como socialización incentivada. Es la forma en la que el adolescente es capaz de integrar todos aquellos aprendizajes emanados del grupo: valores, normas y conductas, que tienen por objeto alcanzar una determinada posición tanto inter como intra grupal. Claes et al., (2005) identifican que los riesgos asociados a esta etapa se expanden cuando el adolecente halla en su grupo de iguales estímulos positivos necesarios como para vincularse a las actividades de su grupo, olvidando otras referencias de entornos normalizados que permitían su ajuste social. Según diferentes investigaciones, este es uno de los puntos de ruptura del adolescente con actividades prosociales que inciden en el desarrollo de diferentes prácticas de riesgo (Scheier, Botvin \& Baker, 1997; Herrero, 2003; He et al., 2004; Marín \& Olivares 2009 y Espada, Morales \& Orgilés, 2013)

Por ende, el cumplimiento pleno de las etapas de socialización capacita a los adolescentes con mayores y mejores competencias en su tránsito hacia la madurez. La educación a lo largo del ciclo vital es un constructo plural que guarda mucha relación con este posicionamiento, ya que parte de la necesidad de "educar no sólo a individuos, sino a aquellos que podrían ampliar nuestro círculo más inmediato" (Hutchinson \& Robertson, Ob. Cit: 138). Así pues, la alfabetización para el ocio es imprescindible para que los adolescentes eviten los riesgos asociados al tiempo libre deconstructivo.

\section{Diseño Metodológico}

Nuestra posición, en metodología gira en torno a los métodos empíricos cuantitativos y cualitativos que se complementan sobre todo cuando nuestro propósito es abarcar la totalidad del objeto de conocimiento. En nuestro caso, los procesos de socialización de adolescentes en el territorio me- ceive through their parents or teachers (Ovejero, Moral \& Pastor, 1998).

Effectiveness is an essential issue related to the group of equals, this is, its ability to position the physical territory and with a direct connection with the risks (Uceda, Pitarch \& Montón, 2012) or on the contrary, virtually, stablishing an abstract relation. Moreover, inside the groups it is generated what Cieslick and Pollock (2002) identify as stimulated socialization. It is the way in which the adolescent is able to integrate all the learnings coming from the group: values, rules and guidelines, which have as an objective to reach a particular inter- and intra-group position. Claes et al., (2005) identify that the risks associated to this stage are expanded when the adolescent finds in his group of equals the positive stimuli needed to connect him to group activities, forgetting different references from normalized environments that allowed his social adjustment. According to different research studies, this is one of the breaking points of the adolescent with pro-social activities that influence in the development of different risk practices. (Scheier, Botvin \& Baker, 1997; Herrero, 2003; He et al., 2004; Marín \& Olivares 2009 \& Espada, Morales \& Orgilés, 2013)

Therefore, the full implementation of the socialization stages empowers the adolescents with more and better skills in their transition to adulthood. Education along the life cycle is a plural construct that is related with this positioning, since part of this need of "educating not only individuals, but those who could expand our immediate circle" (Hutchinson \& Robertson, Ob. Cit: 138). So, literacy is essential for leisure for adolescents in order to avoid risks associated to deconstructive free time.

\section{Methodological design}

Our position in methodology focuses on the quantitative and qualitative empiric methods that are complemented especially when our purpose is to cover the whole object of knowledge. In our case, we deal with the socialization processes of adolescents in the metropolitan area of Valencia City. From

[ 148 ] JOSÉ-JAVIER NAVARRO-PÉREZ, JOSÉ-VICENTE PÉREZ-COSÍN Y SILVIA PERPIÑÁN SIPS - PEDAGOGIA SOCIAL. REVISTA INTERUNIVERSITARIA [1139-1723 (2015) 25, 143-170] TERCERA ÉPOCA 
tropolitano de la ciudad de Valencia. Desde este enfoque iniciamos la presentación de los resultados, primero con datos cuantitativos en forma de gráficos y, segundo los complementamos con los resultados cualitativos del análisis de contenido de las entrevistas a los informantes seleccionados.

\subsection{Objetivos}

a. Conocer las características de los adolescentes escolarizados en el territorio de análisis.

b. Identificar factores de riesgo y de protección que expresan los resultados.

c. Evaluar las principales necesidades sentidas por los adolescentes en los ámbitos de socialización.

d. Proponer medidas inclusivas para un desarrollo democrático y socializador de los adolescentes, capaz de enriquecer las dinámicas comunitarias y de fortalecer el espíritu crítico - reflexivo.

\subsection{Población y Muestra}

La población diana de nuestra investigación viene configurada por adolescentes de entre 12 y 16 años residentes en barrios de acción preferente del Barrio del Cristo (en el municipio de Aldaia), San Jerónimo (en el municipio de Quart de Poblet) y San José (en el municipio de Xirivella), situados en el área metropolitana de Valencia.

La muestra compuesta por adolescentes escolarizados en secundaria obligatoria de institutos públicos, está basada en un muestreo no probabilístico por cuotas (de primero a cuarto curso), como resultado de una consulta previa a los centros escolares sobre la matrícula de cada nivel, grupo y especialidad que tienen en cada uno de ellos. Tratamos de conseguir una representación de los adolescentes basándonos en los perfiles mayoritarios descritos por los profesionales que les atienden. La elección del grupo ha sido aleatoria, primando la facilidad de acceso en torno a las decisiones del equipo directivo del centro.

Presentamos a continuación la ficha de la encuesta a los adolescentes escolarizados como resumen esquemático del proceso metodológico seguido en el desarrollo de la misma. this point we begin our presentation of results, firstly with quantitative data presented in graphics and, secondly we complement them with qualitative results from the analysis of contents from the interviews of the selected informants.

\subsection{Objetives}

a. To know the characteristics of educated adolescents in the analysis territory.

b. To identify risk and protective factors that the results shows.

c. To evaluate the principal needs that the adolescents feel in the socialization circles.

d. To suggest inclusive measures for a democratic and socializing development of the adolescents, capable of enriching the community dynamics and strengthening the critical-reflexive spirit.

\subsection{Population and Sample}

The target population of our research is shaped by adolescents aged 12 to 16 living in neighborhoods of priority action from el Barrio del Cristo (in Aldaia's town), San Jerónimo (in Quart de Poblet's town) and San José (in Xirivella's town), located in the metropolitan area of Valencia.

The sample, composed by educated adolescents from compulsory secondary education from different public high schools, is based on a non-probabilistic sampling on fees (from first to fourth grade), as a result of a previous enquiry to education centers about the enrolment of each level, group and specialization that each group has. We try to obtain a presentation of the adolescents basing on the most popular profiles described by the professionals that helps them. The selection of the group has been random, giving priority to the ones with easy access to the managing team of the center.

Below, we present details of the survey from enrolled adolescents as a simplified summary of the methodological process followed in its development.

The selection of the informants for qualitative analysis, it also has been random according to free participation, always checking before the compliance 
Tabla 1. Ficha de la encuesta escolar. 2013

\begin{tabular}{ll}
\hline Ámbito: & Centros de Secundaria ubicados en barrios de Aldaia, Quart de Poblet y Xirivella. \\
\hline Universo: & Adolescentes matriculados entre 12 y 16 años. \\
\hline Tamaño muestra: & Prevista $n=1.123$. Realizada $n=764$. \\
\hline Afijación: & Alumnos presentes en aula (personas encuestadas "cautivas") por nivel \\
\hline Muestreo: & No probabilístico de tipo opinático (representación de los perfiles educativos) \\
\hline Método selección: & Aleatorio simple. \\
\hline Trabajo campo: & Becarios del IIDL de la Universidad de Valencia. \\
\hline Fecha realización: & Enero-Febrero de 2013. \\
\hline
\end{tabular}

Fuente: Elaboración propia.

Table 1. File in the school survey 2013

\begin{tabular}{ll}
\hline Scope: & Secondary Schools located in neighborhoods Aldaia, Quart de Poblet and Xirivella. \\
\hline Target Pool: & Students enrolled in those centers between 12 and 16 years old. \\
\hline Sample Size: & $\mathrm{N}=1,123$ Initial Pool. Made N=764 Actual Pool \\
\hline Allocation: & Students present in class (respondents 'captive') by level \\
\hline Sampling: & No opinion-based probabilistic (representing educational profiles) \\
\hline Selection Method: & Simple random. \\
\hline Fieldwork: & IIDL Scholars of the University of Valencia. \\
\hline Date: & January-February 2013. \\
\hline
\end{tabular}

Source: authors of this paper.

La selección de los informantes para el análisis cualitativo, también ha sido aleatoria en función de la aceptación libre a la participación, siempre previa comprobación del cumplimiento de los perfiles de inclusión siguientes: grupo y barrio de residencia. Hemos realizado un total de 12 entrevistas en profundidad, una por cada uno de los cuatro cursos de secundaria en centros de cada uno de los tres barrios elegidos.

\subsection{Metodología de Investigación e Instrumentos}

El análisis cuantitativo es de tipo descriptivo (proporción de variables relacionadas con los ítems del cuestionario). Los instrumentos para presentar los resultados de la población y la muestra han sido los gráficos.

En la realización de la parte cualitativa de la investigación hemos fomentado la emergencia de un of the next inclusion profiles: group and residence neighborhood. We conducted a total of 12 in-depth interviews, one for each of the four secondary courses in centers of the selected neighborhoods.

\subsection{Methodology of Investigation and Resources}

Quantitative analysis is descriptive (proportion of variables related to the questionnaire items). The tools to represent the population results and samples were graphics.

In the fulfilment of the quantitative part of the research, we encouraged an open speech and freedom of expression of the informants. We use, spe-

[ 150 ] JOSÉ-JAVIER NAVARRO-PÉREZ, JOSÉ-VICENTE PÉREZ-COSÍN Y SILVIA PERPIÑÁN 
discurso abierto y la libertad de expresión de los informantes. Concretamente, utilizamos las entrevistas en profundidad como técnica idónea. Tratamos de obtener una comprensión detallada en torno al proceso de conocimiento de la realidad social, todo ello desde la perspectiva de los informantes. Las técnicas cualitativas, nos posibilitan un proceso de comunicación real y una riqueza viva del intercambio simbólico que nos permite una recuperación de la subjetividad real y de las relaciones sociales. Se trata de aprehender las experiencias destacadas de las relaciones sociales e institucionales y las valoraciones subjetivas y personales planteadas por los informantes (Taylor \& Bogdan, 1994), facilitando informaciones que pueden ser complementarias a las obtenidas, a través del cuestionario y en la que hemos utilizado un acercamiento metodológico de carácter cuantitativo.

El cuestionario desarrollado incluye los siguientes tipos de ítems: relaciones paternofiliales, rendimiento escolar, conocimiento de la oferta de servicios institucionales dirigidos a los adolescentes en su entorno más cercano, intereses personales y su proyección de futuro hacia la vida adulta; y el consumo de sustancias adictivas.

\section{Resultados}

Los resultados permiten canalizar las propuestas para establecer abordajes y líneas estratégicas que permitan prevenir e intervenir con las mayores garantías de éxito. Por ello, el hecho de investigar en un territorio de realidades diversas, nos permite la obtención de evidencias representativas de la población objeto de estudio que son perfectamente extrapolables a otras experiencias de nuestra realidad social cotidiana.

Al plantearnos el proyecto de investigación, concedimos relevancia e interés a aquellos aspectos en relación simbiótica con la socialización adolescente; es decir, la influencia de las relaciones familiares, las preocupaciones de los adolescentes, los espacios y actividades para el ocio y su relación con los consumos -drogas, estéticas-, los valores, el interés en la escuela o las cuestiones relativas al aprendizaje desde el propio curriculum, los canales de participación y sus conocimientos respecto a la misma, etc. cifically, the in-depth interviews as a suitable technic. We try to obtain a detailed understanding about the learning process of the social reality, always from the informant perspective. Qualitative techniques, enables a real communication process and a vivid symbolic exchange that allows the recovery of a real subjectivity and social relations. We try to apprehend the highlighted experiences from social relations and the subjective and personal assessments considered by the informants (Taylor \& Bogdan, 1994), providing information that can be complementary to those obtained through the questionnaire and in which we used a quantitative methodological approach.

The developed questionnaire includes the following kind of items: parent-child relations, school performance, knowledge of the institutional range of services addressed to adolescents in their immediate environment, personal interests and their future projection to adulthood; and substance abuse.

\section{Results}

Results can direct the proposals to establish approaches and strategies which allow us to prevent and interfere with great guarantees of success. Therefore, the fact of researching a territory with different realities, allows us to obtain representative evidence of the study population that are perfectly extrapolated to experiences of our everyday social reality.

In approaching the research project, we gave relevance and interest to those features with symbiotic relationship with the adolescent socialization; this is, influence of family relationships, adolescents concerns, spaces and leisure activities and its relations with consumptions -drugs, aesthetics-, values, interest in school or learning issues from the curriculum itself, the channels of participation and their knowledge of it, etc.

Next, we present the results ordered, in five large blocks of items or categories of analysis. 
A continuación presentamos los resultados de forma ordenada, en cinco grandes bloques de ítems o categorías de análisis.

\section{a) Las relaciones padres - hijos}

Las relaciones en el entorno del núcleo de convivencia familiar constituyen un importante factor para la estabilidad emocional de los adolescentes, así como para el proceso de socialización de estos.

\section{Composición de núcleos de convivencia}

En relación al parentesco de las personas con las que conviven los adolescentes consultados, los hogares en los que estaba presente el padre fueron el $86 \%$. Por lo que respecta a las madres, éstas estaban presentes en el $97,4 \%$ de los hogares. Los adolescentes que tenían uno o más hermanos/as alcanzaron porcentajes del $77,9 \%$.

La presencia de otros familiares en el domicilio habitual diferentes a la familia nuclear se situó en el $8,3 \%$ de los casos, siendo la presencia de nuevas parejas de los progenitores y abuelos, por este orden, los más representados.

Percepción de las relaciones con los padres y madres

A la pregunta “¿Cómo crees que son las relaciones con tus padres?", los adolescentes consultados las perciben como muy buenas (13,5\%) o buenas (31,1\%), siendo la suma de ambas categorías el 44,6\%, una cifra cercana a la mitad de la muestra. Los porcentajes de adolescentes que percibían como regular la relación con sus padres se situó en el 39,1\%, siendo este ítem el más representativo. Finalmente la suma de los que la percibieron como mala $(11,9 \%)$ y muy mala $(4,4 \%)$ supuso el $16,3 \%$.

Destacamos a este respecto diferentes discursos, que avalan esta categoría:

"Con mis padres no tengo queja. Con decirte que mi madre es mi amiga..." (ADOL-1/12)

"Normalmente bien, menos cuando a ella se le cruza el cable... bueno que a mí también se me va la cabeza que flipas" (ADOL-3/12)

"Uff!!! Mal, bueno muy mal... desde que su novio se vino a vivir a casa, es la muerte, pues no, lo siguiente..."

(ADOL-5/12)

\section{a) Parent-child relations}

The relationships in the core of family life constitute an important factor for adolescents' emotional stability, as well as for their socialization.

\section{Composition of domestic units}

Regarding the relationship of the people who live with the consulted adolescents, households in which the father was present was $86 \%$ the. With regard to mothers, they were present in $97,4 \%$ of households. Adolescents with brothers or sisters reached the $77,9 \%$.

The presence of other relatives in the usual residence different from the family core reached $8,3 \%$ of cases, being the presence of new couples of parents and grandparents, in this order, the most represented.

\section{Perception of relationships with parents}

To the question "How do you think the relationship with your parents is?" surveyed adolescents perceive it as very good $(13,5 \%)$ or good $(31,1 \%)$, being the sum of both categories $44,6 \%$, a figure close to half of the sample. The percentage of adolescents who perceived the relationship with their parents as average was $39,1 \%$, being this item the most representative one. Finally the sum of the ones that perceived it as poor $(11,9 \%)$ and very poor $(4,4 \%)$ was $16,3 \%$.

We highlight in this respect different discourses, supporting this category:

"About my parents I cannot complain. I can tell you that my mother is my friend..." (ADOL-1/12)

"Usually fine, except when she loses the rag... well sometimes I'm out of my head too" (ADOL-3/12)

"Uff!!! Bad, well really bad... since her boyfriend came to live with us, it's the worse..." (ADOL-5/12) 
Gráfico 1. Percepción de las relaciones paterno filiales

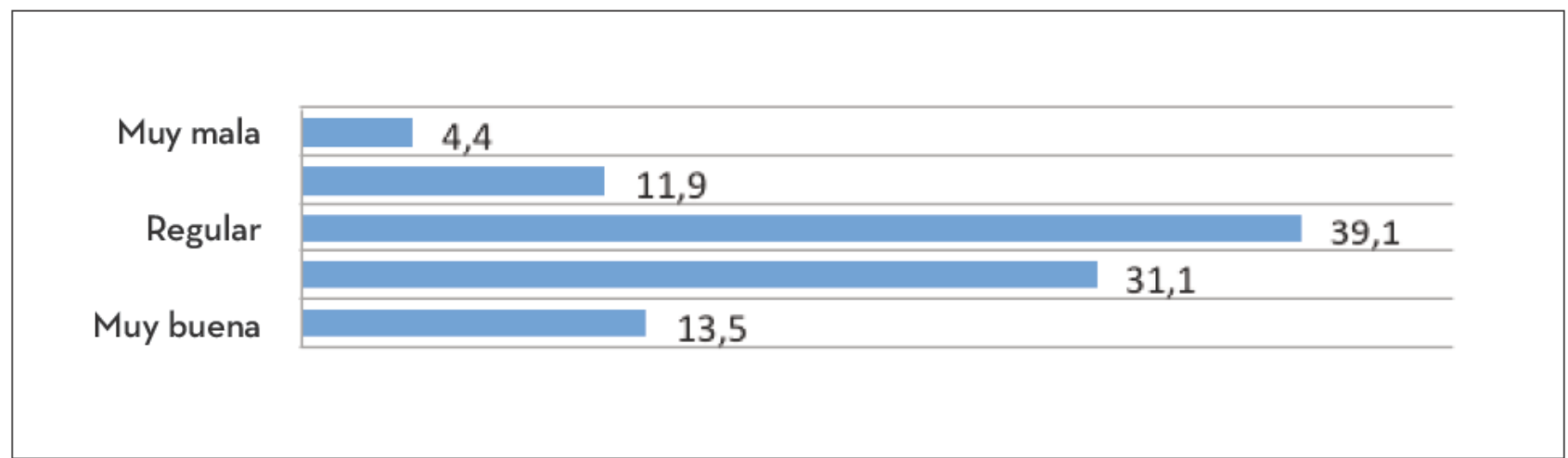

Fuente: Elaboración propia.

Graph 1. Averaged ratings of the reported relationship between parents and children

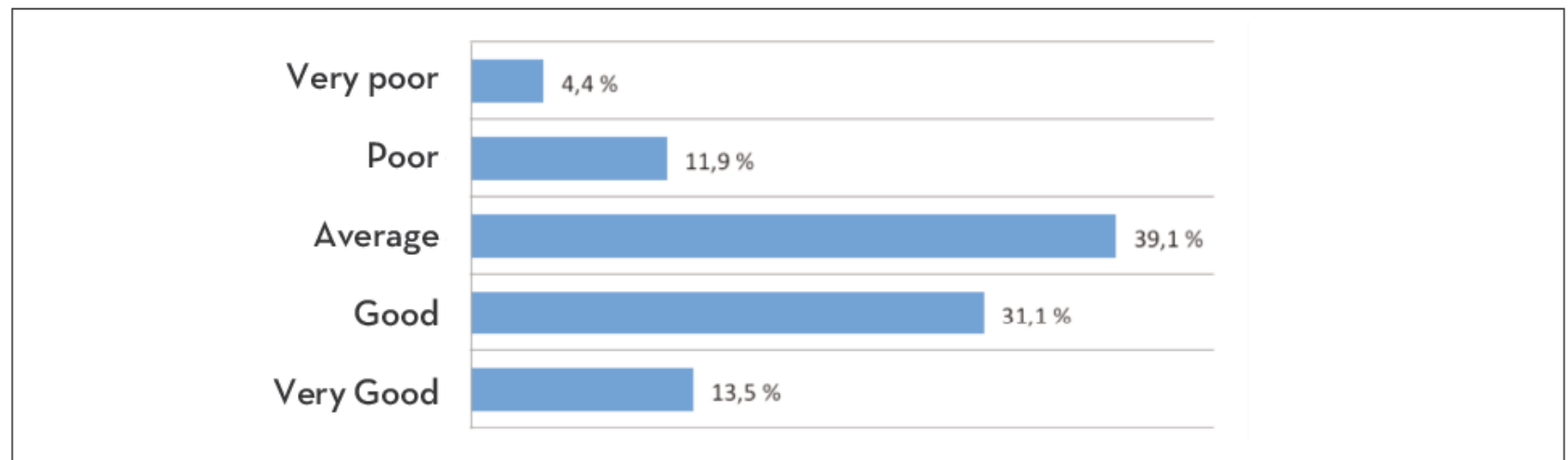

Source: authors of this paper.

Es destacable que la mayoría percibieron como regulares las relaciones con sus progenitores. La aparición de nuevas parejas dificultó la convivencia, y por ende las relaciones entre los diferentes miembros del núcleo familiar.

\section{b) El rendimiento escolar}

Para seguir profundizando en la descripción de la situación de los adolescentes, en este apartado quisimos atender el perfil de la muestra en función del porcentaje que repitió curso y a la valoración que los propios adolescentes hicieron de la relación educativa, complicidad y cercanía hacia sus profesores.

Repetición de curso y consecución de título

Un porcentaje importante $(56,5 \%)$ no repitió curso en ninguna ocasión. Respecto a la situación poco favorable de repetir curso, observando los resultados de la gráfica siguiente, un $26,4 \%$ repitieron curso en una ocasión y, dato a remarcar, un $17,1 \%$ lo hizo dos
It is noteworthy that most of them perceived as average their relations with their parents.

The emergence of new couples complicated the cohabitation between the different members of the family core.

\section{b) The school performance}

In order to go on depth with the description of the situation of adolescents, in this section we wanted to deal with the profile of the sample according to the percentage who retook a grade and the assessment that the adolescents made of the educational value, complicity and proximity towards their teachers.

Repeating a course and degree achievement

An important percentage $(56,5 \%)$ did not repeat any grade. Regarding the unfavorable situation of repeating a grade, observing the results in the chart below, a $26,4 \%$ repeated a course once and, highlighting it, a $17,1 \%$ repeated a course two times or 


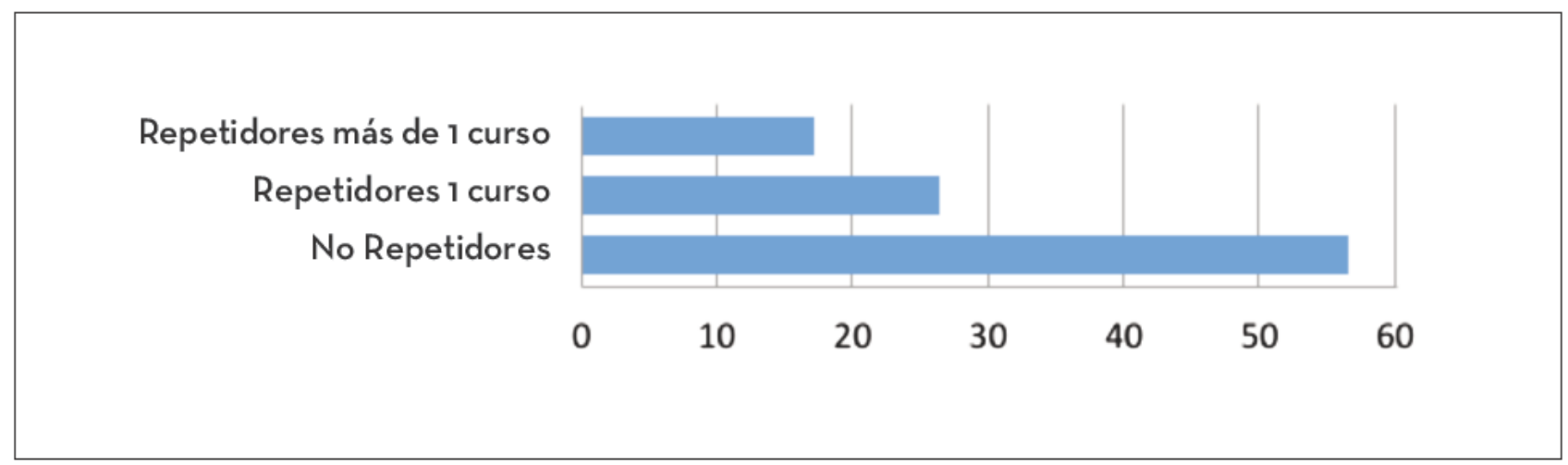

Fuente: Elaboración propia.

Graph 2. Percentage of participants who repeated courses in Secondary Education (ESO)

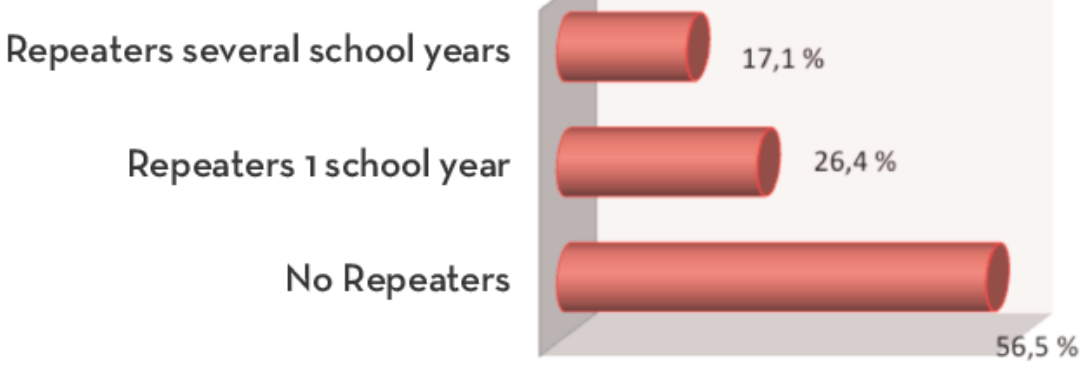

Source: authors of this paper.

o más veces. Los datos no son excesivamente halagüeños, ya que 1 de cada 4 repite curso y casi el 50\% de los estudiantes es repetidor de un curso o más (concretamente el 43,5\%). En nuestro entorno, el porcentaje de estudiantes de países de la OCDE que acceden a obtener el equivalente al graduado en ESO (educación secundaria obligatoria) se sitúa en valores del $89,4 \%^{2}$. Por su parte, en el global del estado español que acceden al título de la ESO, es del $73,4 \% 3$, cifra superior a la media resultante de la muestra informada situada en el $62,4 \%$.

\section{La relación educativa}

La relación educativa implica la existencia de un proceso afectivo y de intercambio en el triángulo formado por el alumnado, el docente y el curriculum. Además, como herramienta metodológica que emana del humanismo, es de uso frecuente en el sector de la educación -tanto formal como no formal- para alcanzar un nivel de comunicación y confianza que facilite el aprendizaje en clave relacional. Por ello, entendimos more. Data are not excessively favorable, because 1 out of 4 repeats a grade and almost $50 \%$ of the students is a repeater of one or more year course (specifically $43,5 \%$ ). In our environment, the percentage of students in OECD countries trying to obtain the equivalent ESO grade (secondary obligatory education) reaches an $89,4 \%$. Meanwhile, if we look at all the people in the Spanish state who are trying to obtain the degree of the ESO, is $73.4 \%$ higher than the average resulting from the reported sample that reaches the $62.4 \%$.

\section{Educational Value}

The educational value implies the existence of an affective process and exchange in the triangle formed by students, faculty members and curriculum.

Also, as a methodological tool that comes from humanism, it is often used in the field of education, to reach a level of communication and trust that facilitates relational learning. 
Gráfico 3. Relación Educativa percibida por el alumnado

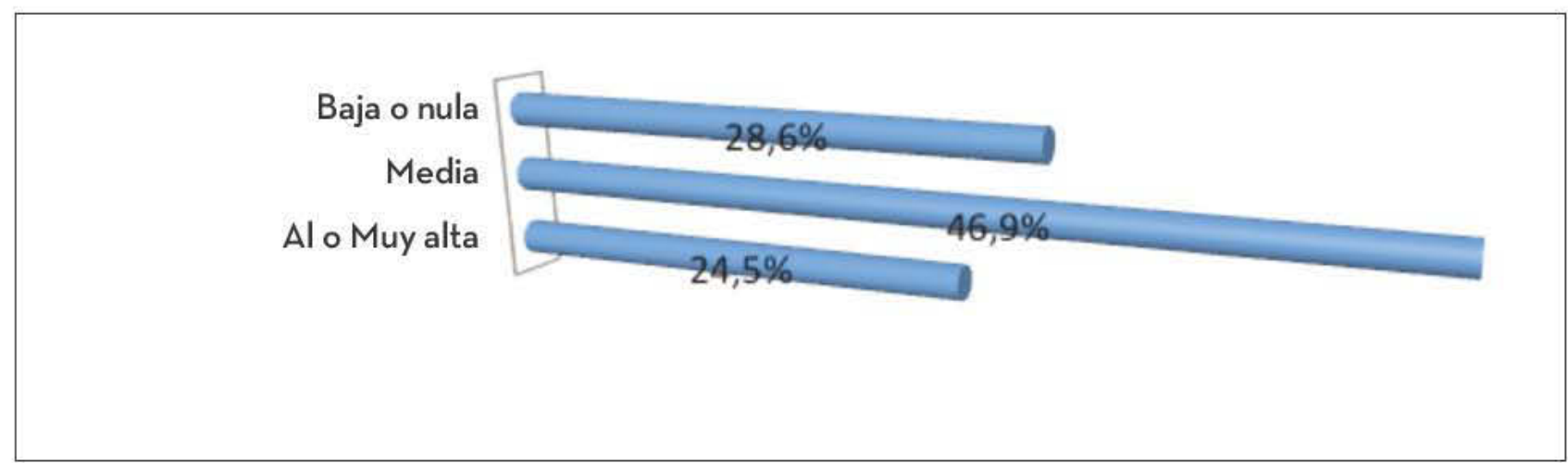

Fuente: Elaboración propia.

Graph 3. Educational relationship perceived by students

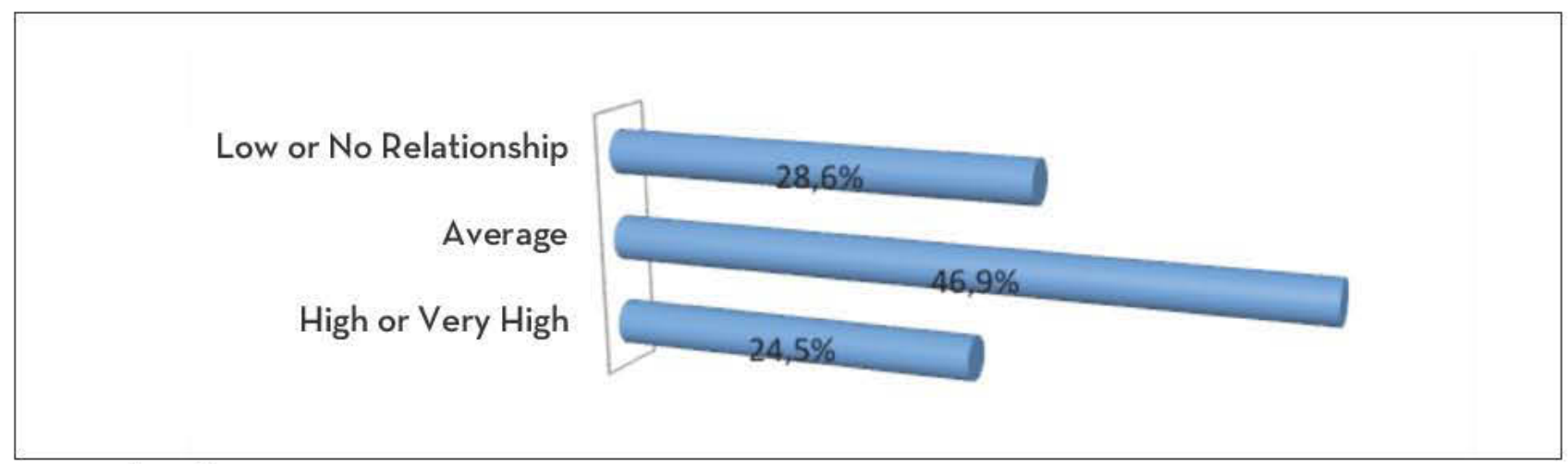

Source: authors of this paper.

significativo extraer datos relativos a la percepción que el alumnado tenía respecto la existencia o no de la relación educativa. Los estudiantes a este respecto contestaron que en un $28,6 \%$, tuvo una incidencia baja o nula en la adquisición de competencias formativas. Refirieron incidencia media un porcentaje del $46,9 \%$ $y$, elevada o de muy alta importancia en la repercusión del docente en la adquisición de conocimientos un $24,5 \%$ de los encuestados

Los resultados dictaminan que solo una cuarta parte de la muestra considera que la motivación del docente fue elevada para lograr sus objetivos curriculares. Factor que armoniza con las tasas de repetición de curso, donde casi la mitad son repetidores. Los alumnos perciben un elevado esfuerzo sobre el trabajo que realizan, refiriendo además que no se sienten ayudados por el sector docente para superar sus fracasos.

Los siguientes discursos avalan esta categoría sobre la relación educativa:

"ellos van a su rollo: si estudias de lujo y si no pues a buscar faena o lo que te salga... mientras no les mo-
Therefore, we considered significant to extract data related to the perception that students had about the existence or non-existence of the educational value.

Students, in this respect, replied that $28.6 \%$ had little or no effect on the acquisition of training skills. They reported an average incidence percentage of $46.9 \%$, and high or very high importance on the impact of the teachers in the knowledge acquisition by $24.5 \%$ of the survey respondents.

The results dictate that only a quarter of the sample believes that teacher motivation was increased to achieve curricular goals. This factor, harmonizes with the course repetition rates, which about half of them are repeaters. Students perceive a high effort on the work they do, besides the do not feel helped by the faculty members to overcome its failures.

The following statements support this category about the educational value:

"They do their own thing: it is cool if you study but if you don't, you look for a job or whatever... as far as you don't bother them" (ADOL-3/12) 
lestes" (ADOL-3/12)

"para míque están hasta los... de tanto cambio. No he repetido profesor en toda la ESO. Me han cambiao de profesora en una misma asignatura 4 veces $y$ en el mismo curso... ¿qué relación educativa de esa quieres que tengamos con ellos?" (ADOL-4/12)

\section{c) Conocimiento de actividades e instituciones socio-culturales comunitarias}

Los datos relativos al conocimiento de las instituciones y recursos comunitarios es importante, ya que desde ella se posibilita la construcción de actividades inclusivas, culturales y orientadas a una socialización positiva. A los participantes se les ofreció una referencia con ubicaciones y actividades de los recursos municipales y se les preguntó respecto el
"I think they are up to their... so much change. I haven't had the same teacher in all the ESO. I had four different teachers just for one subject and in the same year course... how come are we gonna have an educational value with them?" (ADOL-4/12)

\section{c) Knowledge of activities and socio- cultural communitarian institutions}

Data related to knowledge of the institutions and communitarian resources is important, since we can build inclusive and cultural activities, oriented to a positive socialization. Participants were offered a list with locations and activities of municipal resources and were asked about the knowledge about them. The results indicated that $20.3 \%$ were aware of most

\section{Gráfico 4. Participación en Actividades Comunitarias}

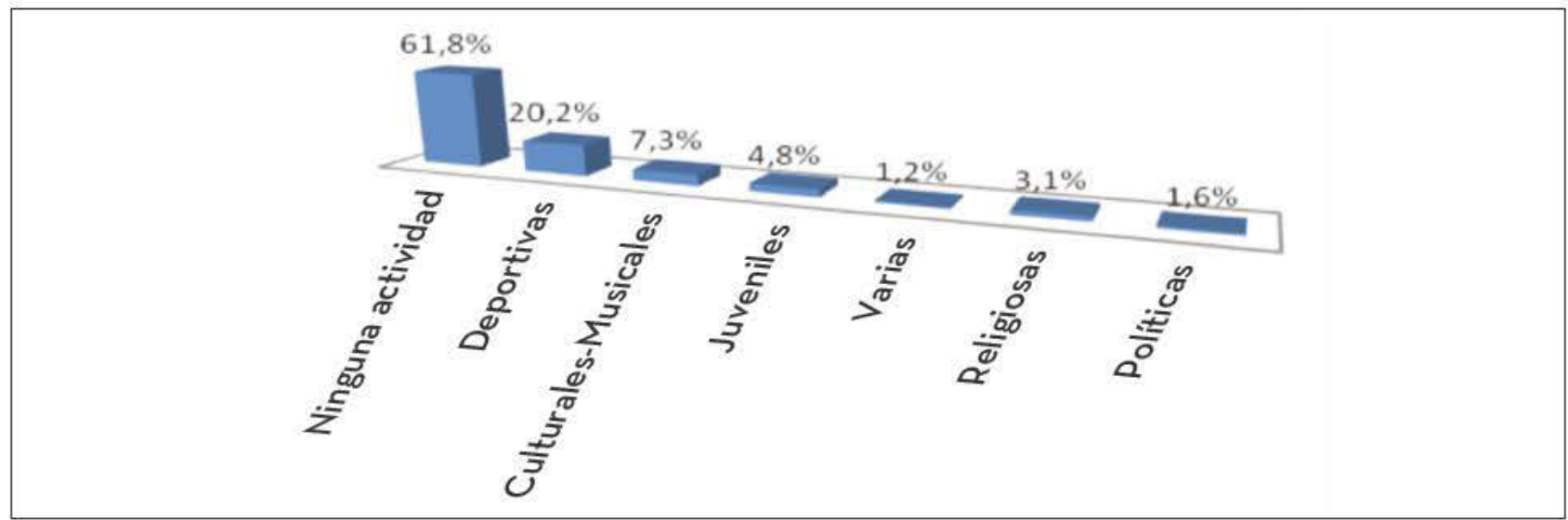

Fuente: Elaboración propia.

Graph 4. Paticipation in community activities

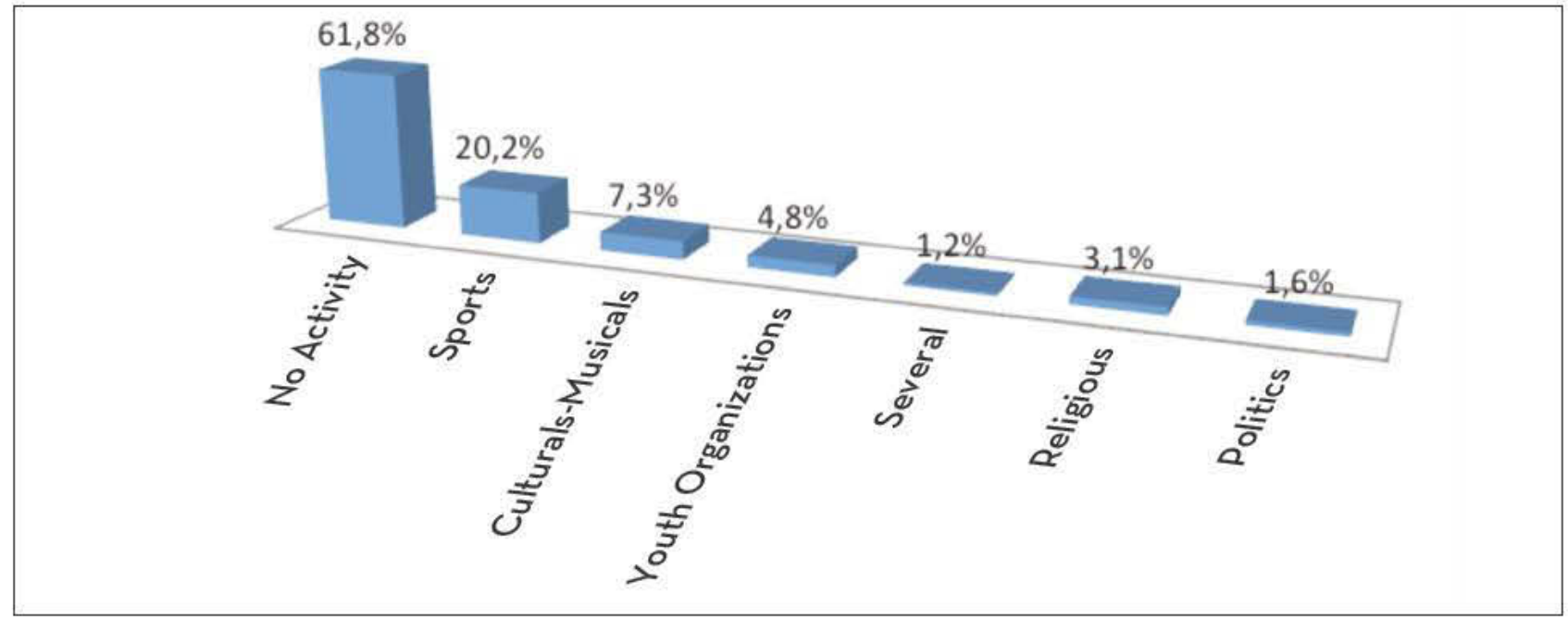

Source: authors of this paper.

[ 156 ] JOSÉ-JAVIER NAVARRO-PÉREZ, JOSÉ-VICENTE PÉREZ-COSÍN Y SILVIA PERPIÑÁN SIPS - PEDAGOGIA SOCIAL. REVISTA INTERUNIVERSITARIA [1139-1723 (2015) 25, 143-170] TERCERA ÉPOCA 
conocimiento sobre ellos. Los resultados indicaron que el $20,3 \%$ eran conocedores de la mayor parte de las instalaciones, recursos y actividades municipales; el $28,6 \%$ conocía al menos la mitad de las instituciones culturales y un $36,9 \%$ era conocedor de menos de la mitad de los recursos destinados a cultura y ocio juvenil. Como nota destacable, los resultados informaron que el $14,2 \%$ de los encuestados desconocía la mayor parte de la oferta.

Vemos que las actividades e instituciones comunitarias que se inscriben en el territorio estudiado presentan escasa ascendencia para los adolescentes. De ellas, las deportivas son las que representan mayor interés y participación con el $21,4 \%$, seguido de culturales - musicales alcanzando un 6,3\%.

\section{Participación en actividades de Ocio No Comunitarias}

Los hábitos en el tiempo dedicado al ocio constituyen un factor importante en el desarrollo de planteamientos preventivos. Generar prácticas de ocio saludable y planificado permite canalizar la conducta prosocial. En este sentido, el gráfico anterior nos mostraba un elevado porcentaje -61,8\%- que se mantenía apartado de las actividades comunitarias programadas. Quisimos investigar en el tipo de actividades de ocio de este perfil de adolescentes, hallando que los principales espacios lúdicos se realizaban en grupo pero de manera no planificada, seguido de actividades de socialización limitada; quedar en el bar o pub (39,3\%), bajar a la calle (24,5\%), jugar a los videojuegos (19,1\%), ninguna actividad $(9,9 \%)$ y otras $(7,2 \%)$.

Esta categoría sobre el ocio no comunitario queda avalada en el siguiente discurso:

"en mi tiempo libre no me gusta que me agobien y si te apuntas al futbol tienes que ir a entrenar [...] tengo otros amigos que van a la Casa de la Música, y les obligan a ir a ensayar los viernes por la noche [...] yo prefiero ir a mi rollo y así no me chino con nadie". (ADOL-3/12)

\section{d) Intereses y objetivos}

Los intereses por los que se mueven los adolescentes constituyen un reflejo para medir el logro de sus objetivos de futuro. Vemos cómo muchos de ellos dan elevado valor al dinero $(23,6 \%)$, a las nuevas tecnologías, la estética y a vestir bien (15,3\%). of the facilities, resources and municipal activities; $28.6 \% \mathrm{knew}$ at least half of the cultural institutions and $36.9 \%$ were familiar with less than half of the resources devoted to culture and youth leisure. It should be pointed out that, results reported that 14.2 $\%$ of respondents did not know most of the offers.

We observe that the activities and community institutions that are registered in the studied territory have low increase for adolescents. Sports are those that present more interest and participation with $21.4 \%$, followed by cultural - musical, reaching $6.3 \%$.

Participation in leisure non-communitarian activities

Habits in leisure time constitute an important factor for the development of preventive approaches. Generating healthy and planned leisure practices permits to lead the pro-social behavior. In this sense, the graph above shows us a high percentage $-61.8 \%$ - that remained away from community activities scheduled. We wanted to investigate the type of leisure activities of this profile of adolescents, finding that the main leisure areas were done in groups but it was unplanned, followed by activities of limited socialization; meeting at the bar or pub (39.3\%), going out $(24.5 \%)$, playing video games $(19.1 \%)$, no activity (9.9\%) and other (7.2\%).

This category of the non-communitarian leisure is supported in the following speech:

"In my spare time I do not like to be harassed and if you join a football team, you have to go to training [...] I have other friends who go to the House of Music, which requires them to go to rehearse on Friday night [...] l'd rather do my own thing and so I don't get mad with anyone" $(A D O L-3 / 12)$

\section{d) Interests and objectives}

The interests why adolescents are moved constitute a reflection to measure the achievement of their future goals. We see how, many of them, give high value to money (23.6\%), to new technologies, aesthetics and dress well (15.3\%). However, we notice 


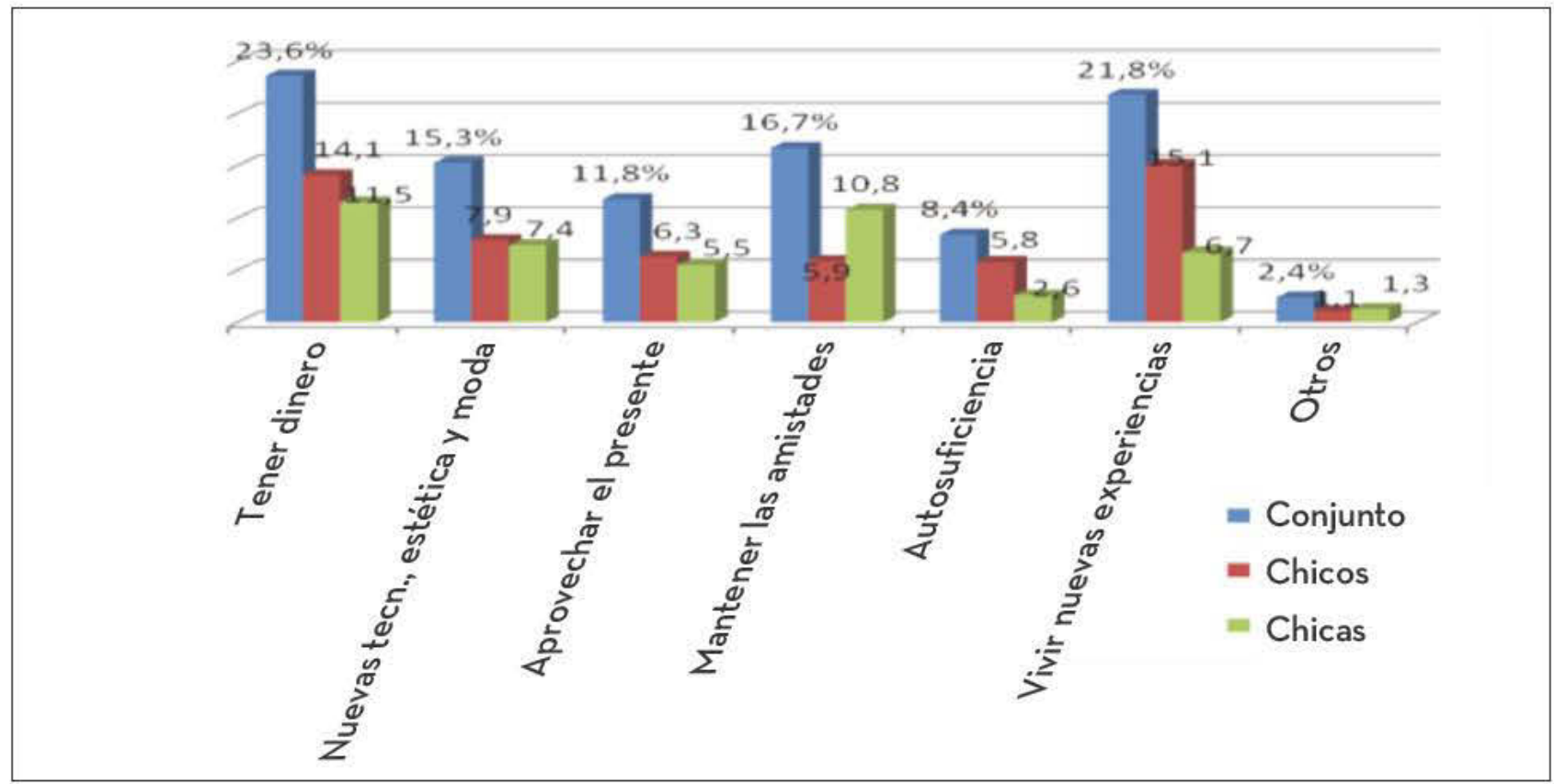

Fuente: Elaboración propia.

Graph 5. Repetición de curso en ESO

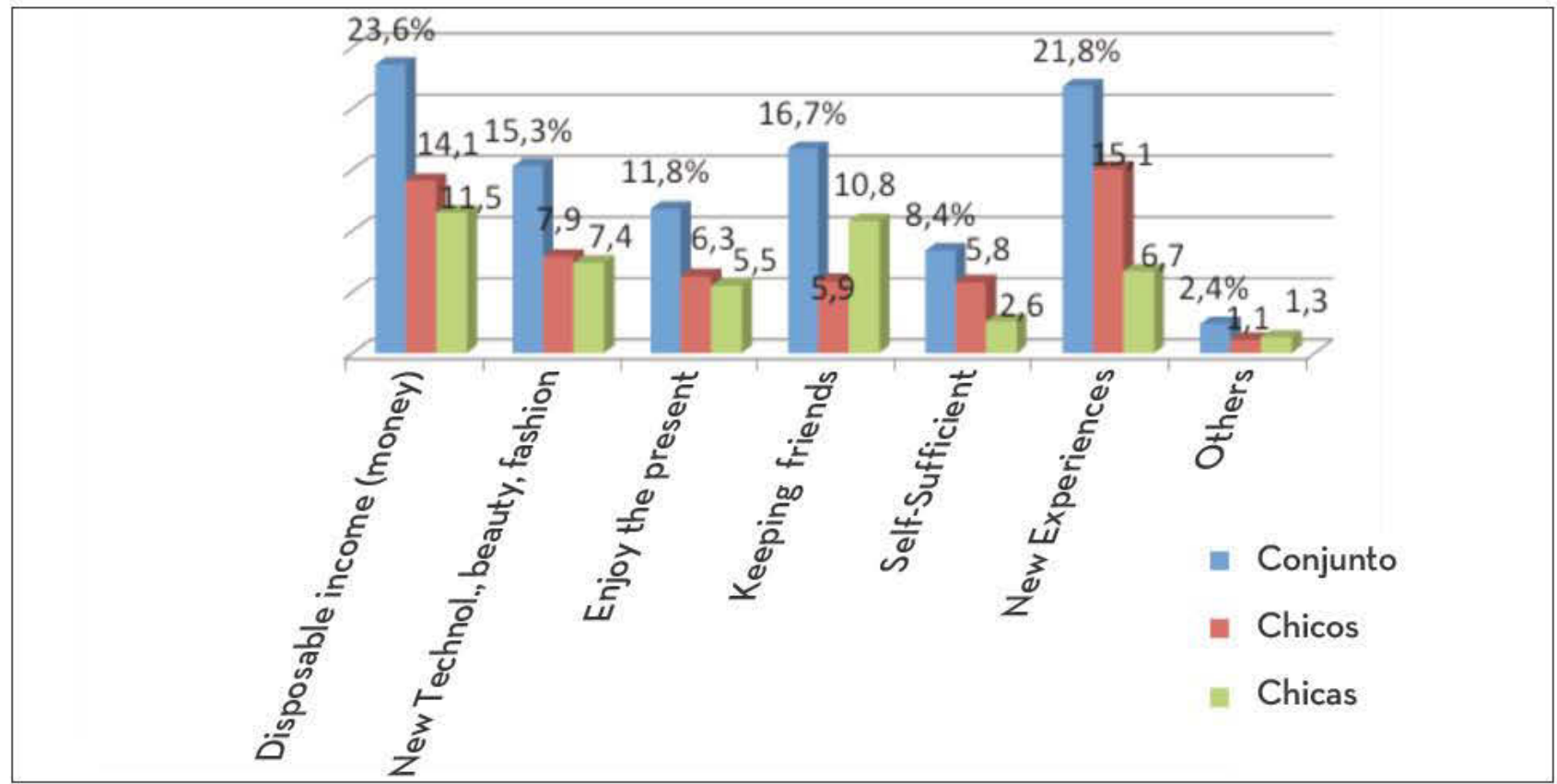

Source: authors of this paper.

Vemos sin embargo como aparece señalado disfrutar el presente $(11,8 \%)$, por otro lado elevan en importancia las relaciones afectivas y de amistad entre iguales (16,7\%). Un elemento que nos llamó poderosamente la atención fue la importancia que dieron a vivir experiencias nuevas (21,8\%). Del mismo modo aunque en un nivel inferior motivaron la autosufi- that enjoying the present appears highlighted (11.8\%), on the other side the importance of affective and friendly relationships among peers raises ( $16.7 \%$ ).

One item that caught our attention was the importance given to live new experiences ( $21.8 \%$ ). Similarly, although at a lower level, they promoted self-sufficiency as a variable in $8.4 \%$ of cases. We 
ciencia como variable en un $8,4 \%$ de los casos. Destacamos que el esfuerzo, la tolerancia o perseverancia para alcanzar estos objetivos no aparece en ningún momento en la lista de prioridades de los adolescentes.

La gráfica permite observar cómo las relaciones de amistad inciden en mayor importancia para las chicas que en los chicos y cómo vivir nuevas experiencias es para los chicos adolescentes los que, con mayor frecuencia, buscan nuevas sensaciones.

La categoría que describe los intereses de los adolescentes está avalada por los siguientes discursos:

"Lo único a lo que no renunciaría es a mis amigas" (ADOL-1/12)

"todo lo nuevo que me ha pasado, en verdad me gusta.

Aquí en el barrio siempre es lo mismo: este que si pin, el otro que si pan... A mí me gusta ver mundo, conocer gente, probar cosas, ir a sitios nuevos..." (ADOL-3/12)

El resto de ítems relacionados con disfrutar del poder adquisitivo y la autosuficiencia económica, el uso y mantenimiento de nuevas tecnologías y la moda se muestran muy parejos o levemente tendentes para uno u otro sexo. El análisis cualitativo de los discursos así lo avala:

“...pues pienso, ¿̇qué haría yo sin mi móvil?"(ADOL-1/12)

"Ja! El futuro que espere, que está muy lejos" (ADOL-

2/12)

\section{e) Relación directa con el consumo de drogas}

A los adolescentes que residen en entornos sometidos a la dificultad, se les presupone una mayor asociación con los riesgos. En este sentido, el contacto con las drogas se ha elevado en diferentes experiencias a considerarse como objetivo prioritario. Por ello, nos interesaba conocer cuál era el nivel de asociación con ellas.

\section{Consumos y tipos}

A la pregunta de si habían consumido sustancias adictivas, contestaron afirmativamente un $79,8 \%$ de los adolescentes encuestados. De estos un 55,2\% afirmaba haber consumido más de una droga y un 24,6\% solamente una. Preguntados por las dos sustancias de consumo más frecuentes, los resultados emphasize that the effort, tolerance and perseverance to achieve these goals does not appear at any point in the adolescents' priorities list.

The graphic allows us to observe how friendships affect girls more than boys and frequently; it is the boys, the ones who seek for new experiences.

The category that describes the interests of adolescents is supported by the following statements:

"The only thing that I would not give up is my friends" (ADOL-1/12)

"Every new thing that happened to me, I really like it. Here in the neighborhood is always the same, coming and going... I like to see the world, meet people, try things, go to new places..." (ADOL-3/12)

The rest of items related to enjoy the purchasing power and economic self-sufficiency, the use and maintenance of new technologies and fashion are balanced or slightly tending to one or another sex. The qualitative analysis of the speeches supports it this way:

"...so I think, what would I do without my cell phone?" (ADOL-1/12)

"Ha! Future can wait, it is far away" (ADOL-2/12)

\section{e) Direct relation with substances use}

Adolescents living in environments with difficulty are presupposed to have a greater association with the risks. In this sense, the contact with drugs has increased in different experiences until it is considered a priority objective.

Therefore, we wanted to know the level of association with them.

\section{Consumption and kinds}

When asked if they had consumed addictive substances, $79.8 \%$ of the surveyed adolescents answered affirmatively. Out of these, $55.2 \%$ reported to have used more than one drug and $24.6 \%$, only one.

When asked about the two most common substances they consume, the results reported $22.4 \%$ 


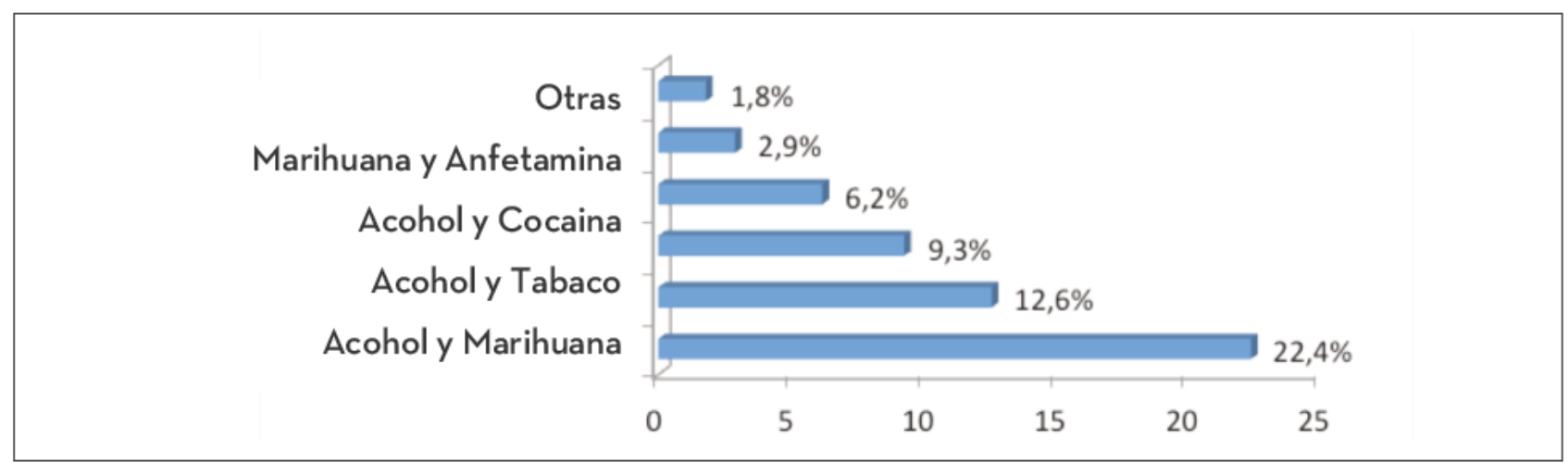

Fuente: Elaboración propia.

Graph 6. Relevance in the substance use by adolescents

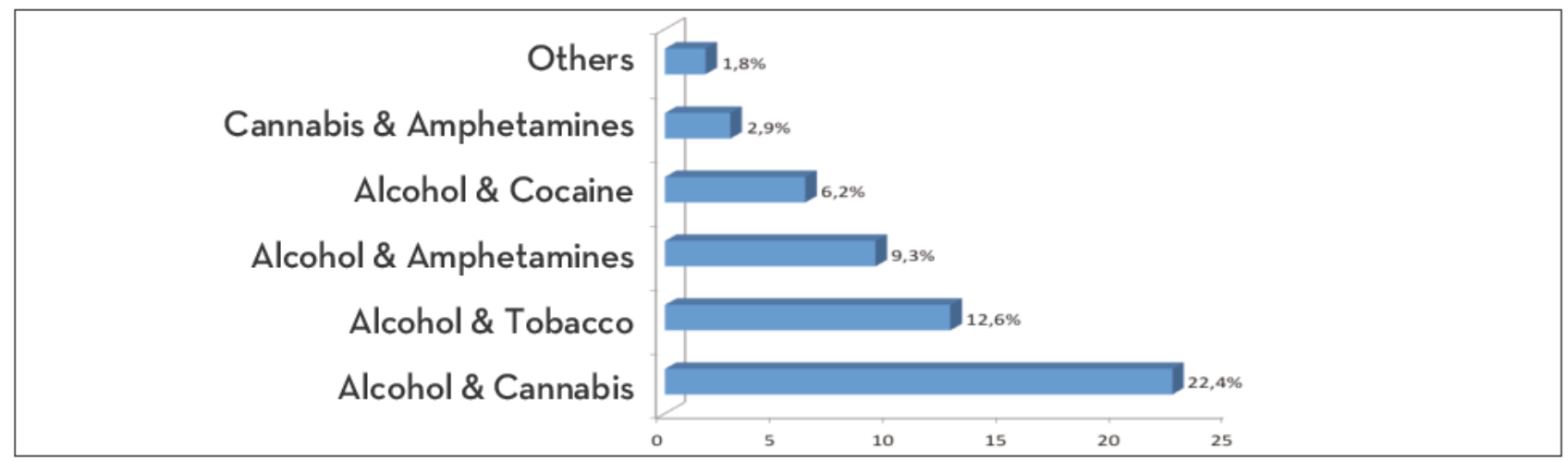

Source: authors of this paper.

informaron de alcohol y marihuana 22,4\%, alcohol y tabaco el 12,6\%, alcohol y anfetaminas en 9,3\%, alcohol y cocaína $6,2 \%$, marihuana y anfetaminas en $2,9 \%$ y otras asociaciones en $1,8 \%$ de los casos.

De aquellos consumidores de una sola sustancia, destacaba el alcohol con un $13,2 \%$, seguido del tabaco, con un $9,3 \%$ tras otras con un $2,1 \%$. El gráfico demuestra cómo tanto el alcohol como la marihuana representan un consumo de elevada atribución para los adolescentes.

\section{Espacios y consumo}

Nos interesó identificar los principales espacios para el consumo de drogas por parte de los adolescentes. La asignación del consumo se realiza deliberadamente, y en base a ella, la información ofrecida fue: en el propio domicilio familiar con un $35 \%$, la calle $29 \%$, entornos de ocio nocturno discotecas y pubs $24 \%$, en el instituto $7 \%$ y otros $5 \%$.

La naturalidad que expresan los discursos de los adolescentes avala esta categoría sobre consumos alcohol and cannabis, alcohol and tobacco $12.6 \%$ alcohol and amphetamines in 9.3\%, 6.2\% alcohol and cocaine, cannabis and amphetamines $2.9 \%$ and other associations in $1.8 \%$ of the cases.

Those who consume a single substance, we highlight alcohol with $13.2 \%$, followed by tobacco, with $9.3 \%$ and some others with $2.1 \%$.

The graphic shows how both alcohol and cannabis consumption is highly entitled to adolescents.

\section{Spaces and consumption}

We wanted to identify the different spaces for drug use by the adolescents. The allocation of consumption is done deliberately, and based on it, the information provided was: at their own family house with $35 \%$, the street $29 \%$, night leisure environments, clubs and pubs $24 \%$, in high school $7 \%$ and others $5 \%$.

The naturalness that the adolescent's speeches express supports this category about consumption 
de sustancias adictivas. Así lo encontramos en los siguientes fragmentos:

"antes de dormir me hago un porrico... y a la camica con los angelicos" (ADOL-2/12)

"en los servicios de las discotecas te avisan, prohibido consumir estupefacientes... y entras te ves toda la peña pintando... porque les obligan porque ya saben que eso no lo cumple ni la que friega los meaos" (ADOL-3/12)

También nos cuestionamos la percepción que los adolescentes tenían respecto a las posibilidades de sufrir dependencia de las drogas. El 93,6\% consideró que las drogas generan problemas de dependencia, sin embargo un 52,3\% auto-percibió controlar su consumo, un $28,7 \%$ percibió que no controlaba su consumo y podía resultar para sí mismo un riesgo a medio plazo y un $12,6 \%$ No supo o No contestó a este respecto.

Los datos indican que los adolescentes poseen información respecto de las causas que generan sometimiento al consumo de sustancias, pero identifican en su mayoría para sí mismos escasas

Gráfico 7. Percepción sobre los consumos of addictive substances. This is found in the following passages:

"before I go to sleep I roll a joint... and then beddie-bye" (ADOL-2/12)

"bathrooms in nightclubs warn you, it is forbidden to consume drugs ... and when you walk in you see all the dudes doing lines ... because they are forced to do so because they know that not even who cleans the piss does it" (ADOL-3/12)

We also question the perception that adolescents had of the possibilities of suffering drug dependency. A $93.6 \%$ felt that drugs generate dependency problems, but $52.3 \%$ self- perceived they can control their consumption, $28.7 \%$ felt they did not control their consumption and could be a half-term risk to themselves and $12.6 \%$ did not know or did not answer regarding this.

The data indicate that adolescents have information regarding the causes of subjection to substance use, but most of them identify themselves scarce possibilities to generate

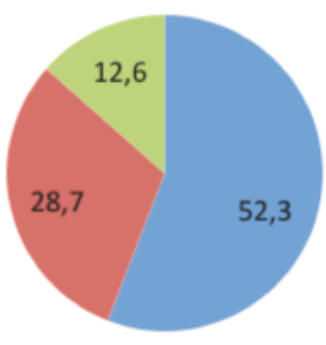

- Auto-Control sobre su consumo $=$ No control sobre el consumo $=\mathrm{Ns} / \mathrm{Nc}$

Fuente: Elaboración propia.

Graph 7. Percentage of perception of drug use

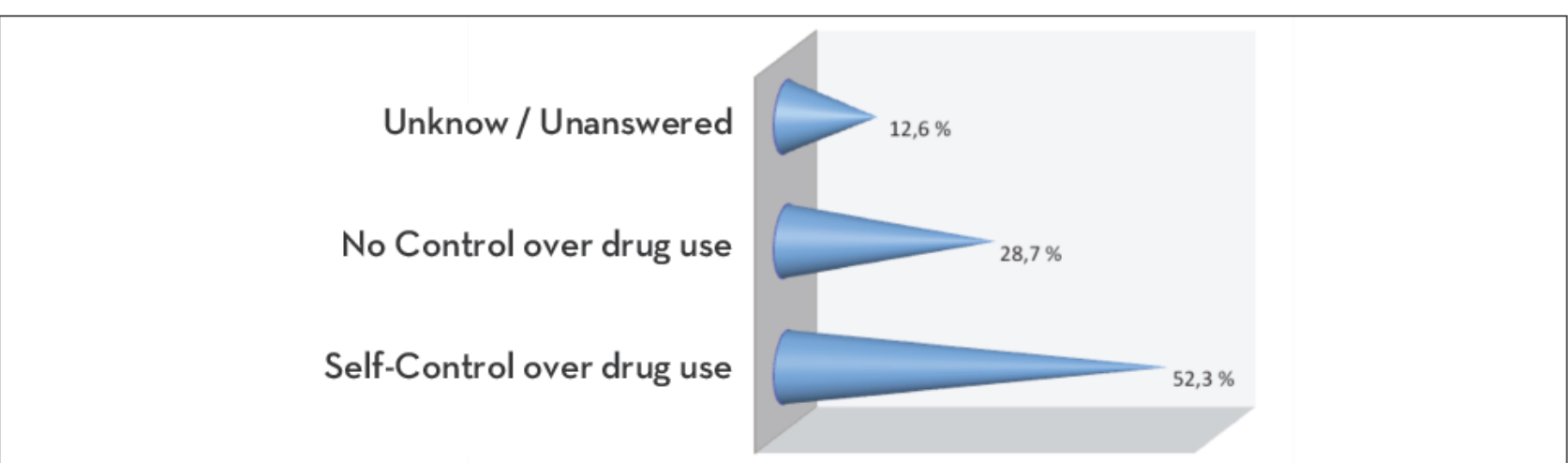

Source: authors of this paper.

EL PROCESO DE SOCIALIZACIÓN DE LOS ADOLESCENTES: ENTRE LA INCLUSIÓN Y EL RIESGO. RECOMENDACIONES... [ 161 ] SIPS - PEDAGOGIA SOCIAL. REVISTA INTERUNIVERSITARIA [1139-1723 (2015) 25, 143-170] TERCERA ÉPOCA 
posibilidades de generar dependencia ya que alegan reconocer adecuadamente sus niveles de control sobre las sustancias. Poco menos de $1 / 3$ de los consultados manifestó cierto escepticismo ante sus capacidades de autocontrol y un $12,6 \%$ no supo o desconsideró esta cuestión.

\section{Conclusiones y Propuestas}

Hemos considerado, clasificar en diferentes segmentos de análisis las evidencias derivadas del proceso de sistematización de las conclusiones. Así, presentamos las siguientes:

\section{Los adolescentes, ¿en qué mundo viven -vivimos-?}

Es de importancia para los adultos conocer la forma de vida e idiosincrasia de los adolescentes, los vínculos que alcanzan, la proyección de sus manifestaciones, de qué manera se relacionan, comparten, crecen, incorporan sus afectos y se transforman. A los padres les interesa conocer la realidad de los hijos para supervisarla y en su caso limitarla. Por su parte, a los profesionales de la intervención socioeducativa, les incumbe analizar esta evolución para determinar prácticas preventivas y constructivas que permitan una socialización con mayores garantías y menos riesgos.

El cambio social ha supuesto modificaciones en las estructuras de convivencia, que por otro lado han revolucionado las pautas de crianza y límites entre padres e hijos. El gráfico 1 nos mostraba la dificultad que encuentra el adolescente para reducir las diferencias que le separan entre las voluntades propias y las de los progenitores.

Sobre estas distancias entre la coherencia y los fines educativo-relacionales ofrecidos desde la institución familiar, resultan interesantes las aportaciones de Tarín y Navarro (2006) al reflejar el doble mensaje que los padres, llegan a infundir en los hijos. A este respecto, refieren los autores que "los adolescentes, confundidos, ya no saben si su padre es compadre o si su madre lo es como tal o ha cambiado su rol por el de compañera de piso"(2006: 74). Ello implica que asistimos a una metamorfosis en las relaciones familiares, en la que los límites se vislumbran cada vez más difusos. dependency because they claim to recognize adequately their level of control over the substance.

Less than $1 / 3$ of the respondents expressed some skepticism about their ability to self-control and $12.6 \%$ did not know or did not considered this issue.

\section{Conclusions and Proposals.}

We have considered, classifying into different segments of analysis the evidence derived from the systematization process of findings. Thus, we present the followings:

\section{Adolescents, what world do they-we live in?}

It is important for adults to know the lifestyle and idiosyncrasies of adolescents, the bonds they reach, the projection of its forms, how they connect, share, grow, incorporate and transform their affections. Parents are interested in learning about the reality of their children to supervise it and limit it if necessary. On the other side, the professionals of socio-educational intervention are interested in analyzing these developments to determine preventive and constructive practices that will allow socialization with greater guaranties and fewer risks.

Social change has led to modifications in the structures of cohabitation, which on the other hand have revolutionized the parenting patterns and parent-child boundaries. Graphic 1 showed us how difficult it is for adolescents to reduce the differences that separate them between their own free will and the ones from their parents. About these differences between coherence and relational-educative purposes offered by the family institution, we find interesting contributions from Tarín and Navarro (2006) when reflecting the double message that parents come to instill in their children.

According to this, the authors relate that "the confused adolescent, does not know if his father is his pal or his mother is his mother or has changed her role to roommate" (2006: 74). This implies that we are witnessing a metamorphosis in family relationships, in which the limits are increasingly blurred.

[ 162 ] JOSÉ-JAVIER NAVARRO-PÉREZ, JOSÉ-VICENTE PÉREZ-COSÍN Y SILVIA PERPIÑÁN 


\section{Valores, estéticas y otros derivados}

Los valores implican un especial significado y atendiendo al uso o peso que se le da, se mantienen, desaparecen o se transforman. Por ello, el significado social que se les atribuye es un factor influyente para determinar su mantenimiento o evolución. Atendiendo a las nuevas formas de conducta, corremos el riesgo de que algunos valores sufran una involución desde su concepción original. Es decir, por ejemplo el valor de la tenacidad y la constancia ha sido siempre considerado como elemento de aprecio; sin embargo, corren tiempos en los que no importa el cómo, sino el qué. Lo importante ahora, es, qué tienes y no cómo lo consigues. Esto mismo afecta a otras cuestiones como por ejemplo la autenticidad versus la imitación, el esfuerzo versus la tolerancia al fracaso, etc.

En este sentido, Scheler (2000: 196) plantea que “los jóvenes, como los adultos, se enfrentan a un mundo de problemas y decisiones que reflejan la complejidad de la vida del ser humano. En estas decisiones están en juego los valores como fuerzas directivas de acción. Éstos con frecuencia entran en conflicto; en parte por la poca claridad del sistema de valores de la sociedad y la desorientación de la existencia humana". Es decir, que no sólo son los adolescentes responsables de ese cambio de rumbo en cuanto al esfuerzo, la coherencia, la racionabilidad, sino que alimentados por la sociedad, se mueven al ritmo que dictan los materialismos de las modas, las nuevas tecnologías, la estética y los consumos.

Tal como hemos definido, las vanguardias dominan el espacio socio-cultural, y en él, las adolescencias que describimos se sienten atraídas por la estética del descontrol, el éxito del abandono, el deseo de los bienes materiales y de drogas que permiten volar en un mundo tan paralelo como fantástico e irreal. Hablamos de adolescentes que han crecido con más derechos, más libertad, más conocimiento, más posibilidades, pero también con más sentimiento de fracaso en un mundo más competitivo y materialista; alejados de la asunción de responsabilidad, que huyen de sus frustraciones y que construyen una autoestima paralela en espacios de dificultad. Así pues, no pocos son los insatisfechos con su cotidianeidad, frustrados con sus

\section{Values, aesthetics and other derivates}

The values imply a special meaning and considering the use or importance we give it, they remain, disappear or are transformed. Therefore, the social meaning we give them is an influential factor to determine if they remain or evolve. In response to new behavior, we run the risk that some values suffer an involution from its original conception.

That is, for example, the value of tenacity and perseverance has always been considered as an important element; however, nowadays it does not matter how but who. What matters now is what you have and not how you get it. This also affects other issues such as authenticity versus imitation, effort versus failure tolerance, etc.

Thus, Scheler (2000: 196) argues that "young people, like adults, are facing a world of problems and decisions that reflect the complexity of the human being's life. In these decisions, values as guideline forces for action are at stake. They often come into conflict; in part by the lack of clarity of the value system of the society and the confusion of human existence"

That is, not only adolescents are responsible for this shift in terms of effort, consistency, reasonableness, but fed by society, they change according to materialism of fashion, new technologies, aesthetics and consumption.

As we have defined, the vanguard controls the socio- cultural space, and in it, the adolescences that we describe are attracted by the aesthetics of chaos, the abandonment success, the desire for material goods and drugs that allow them to fly to a world as parallel as fantastic and unreal.

We are talking about adolescents who have grown up with more rights, more freedom, more knowledge, more possibilities, but also with a higher feeling of failure in a competitive and materialistic world; away from the acceptance of responsibility, running away from their frustrations and building a parallel self-esteem in a space of difficulty.

Thus, not a few are dissatisfied with their daily life, frustrated with their relationships at home, demoralized by their surroundings and with uncertain hopes for the future. The adolescent's speech focuses the excitement of approaching the unknown to get away from routine. 
relaciones en el hogar, desmoralizados por lo que les rodea y con dudosas esperanzas de futuro. El discurso de los adolescentes focaliza la ilusión de aproximarse a lo desconocido para salir de las rutinas.

\section{¿Nostalgia de tiempos pretéritos?}

El estudio de la realidad que rodea los contextos tanto de desarrollo como de riesgo de los y las adolescentes, ha sido desde principios del Siglo XX objeto de reflexión desde diferentes disciplinas científicas. Actualmente los paradigmas psicosociales que giran en torno a la modificación del comportamiento cohabitan con otras perspectivas pedagógicas más centradas en una óptica transversal de acompañamiento cotidiano y en la recuperación integral del individuo.

Los adolescentes son objeto de cuestionamiento constante: "cómo están", "cómo han cambiado", "ya no son los de antes"... Afirmaciones de este tipo, suelen atribuirse a las añoranzas del pasado y forman parte de manera recurrente del imaginario colectivo. Es cierto que los adolescentes han cambiado, pero también lo ha hecho la sociedad en la que viven. En este sentido las pautas globales han condicionado, a largo plazo, sobre todo en estas dos últimas décadas los comportamientos y los patrones de control de los jóvenes. La sociedad global está en constante tránsito, es mutable, capaz de flexibilizar los procesos más rígidos e intercambiar las estructuras periféricas en auténticos nexos de transversalidad.

\section{Calidad de vida y gestión de riesgos}

Así pues, son numerosos los riesgos que asumen por inercia, los adolescentes que residen atrapados en la sociedad del bienestar; decían McLuhan y Fiore (1967) que "el medio es el mensaje" y atendiendo a ello, los adolescentes proyectan sus riesgos mediante sus comportamientos y sus modos de socialización. Los resultados inciden en que los adolescentes se preocupan por el presente (Gráfico 5) y en el anhelo de vivir nuevas experiencias, que en ausencia de mecanismos de ajuste y control pueden suponer una entrada a los circuitos de riesgo.

\section{Nostalgia for bygone days?}

The study of the reality surrounding development contexts and risk contexts as well as those ones of the adolescents, has been since the early twentieth century the subject of reflection from different scientific disciplines.

Nowadays, psychosocial paradigms that revolve around behavior modification cohabit with pedagogical perspectives, focused on a daily accompaniment transverse optic and the full recovery of the individual.

Adolescents are constantly questioned, "how they are", "how they have changed ", "they are not what they used to be"... Statements of this type are often attributed to the nostalgia of the past and belong to the collective imagination in a recurring way. It is true that adolescents have changed, but so has changed the society in which they live.

Thus, global guidelines have influenced, in a long term, especially in the last two decades the behavior and control patterns of adolescents.

Global society is in constant transition, it is mutable, capable of relaxing the rigid processes and exchange peripheral structures in transversal links.

\section{Quality of life and risks management}

Thus, there are many risks that adolescents, living trapped in the welfare state, take by inertia; McLuhan and Fiore said (1967) that "the means is the message" and according to this, adolescents project their risks through their behavior and ways of socialization. The results show that adolescents care about the present (graph 5) and the desire for new experiences, and, in the absence of adjustment and control mechanisms they can be an entrance to the risk circuits.

The results from the investigation left us a disturbing reflection about the limited knowledge by

[ 164 ] JOSÉ-JAVIER NAVARRO-PÉREZ, JOSÉ-VICENTE PÉREZ-COSÍN Y SILVIA PERPIÑÁN SIPS - PEDAGOGIA SOCIAL. REVISTA INTERUNIVERSITARIA [1139-1723 (2015) 25, 143-170] TERCERA ÉPOCA 
Los resultados derivados de la investigación nos dejaron una preocupante reflexión en torno al escaso conocimiento por parte de los adolescentes de las actividades y recursos culturales comunitarios ubicados en su propio entorno. Es visible y representativa la nula ascendencia que para estos supone las actividades comunitarias y su implicación en actividades prosociales. Los datos obtenidos coinciden con las investigaciones de Rubio (2009) al identificar que la cultura y consumo de ocio se ha orientado hacia aspectos individuales, perdiendo la identificación grupal del espacio lúdico - cultural. Divertirse a partir de la tecnología ya creada, que no requiere imaginación para inventar, imaginar, ingeniar, innovar... supone una pérdida objetiva y concluyente del propio juego. El territorio físico ha perdido su ascendencia en el adolescente, pasando a ocupar un escalón preferencial el espacio virtual (Livingstone, 2013).

La pérdida de la presencia grupal en las actividades lúdicas y culturales permite que ese espacio se individualice y por tanto, pierda esa capacidad resocializadora, de resolución de conflictos interpersonales y en definitiva, de aprendizaje que encierra el propio juego. Todo ello, acompañado de una excesiva protección a socializar la diferencia, expresa que la experiencia comunitaria haya perdido la referencia que asumió durante décadas.

El medio, es decir, la representación del espacio cotidiano, configura una identidad que va más allá del mensaje que se transmite. Puig (2013) explica que "solo desde el conocimiento de la realidad que generan las situaciones de dificultad en el contexto físico, lúdico, formativo o laboral de los adolescentes, nos será posible profundizar en el conocimiento de las motivaciones individuales que convierten una conducta fortuita en una práctica cotidiana y permite elaborar estrategias para su recuperación". Esta realidad globalizada nos aproxima a disfrutar de una calidad de vida "cosificada"; la creatividad es un supuesto que pocas ocasiones forma parte del inventario adolescente y ello repercute en un estancamiento de su experiencia vital.

\section{Propuestas para una ciudadanía activa y sostenible}

Entendemos fundamental comprender e interpretar las huellas que nos dejan los adolescentes que vi- some part of adolescents in activities and community cultural resources located in their own environment.

It is visible and representative the inexistent raising that the community activities implies for them and its involvement in prosocial activities.

The data obtained coincides with Rubio's investigations (2009) when identified that culture and leisure consumption was directed towards individual aspects, losing the group identification of the recreational-cultural areas.

To have fun from the already created technology that requires no imagination to invent, imagine, devise, innovate ... represents an objective and definitive loss of the game itself.

The physical territory has lost its ascendancy in the adolescent, occupying now a preferential step the virtual space (Livingstone, 2013).

The loss of group presence in recreational and cultural activities allows the space to be individualized and therefore, to lose that re-socializing capacity and, interpersonal conflict resolution, and ultimately, learning that contains the game itself. All this, is accompanied by an excessive protection to socialize the difference, so it expresses that community experience has lost the reference assumed for decades

The ways, this is the representation of everyday space, sets up an identity that goes beyond the message conveyed.

Puig (2013) explains that "only from the knowledge of reality that create difficult situations in a physical, recreational, educational and labor context of adolescents, it will be possible to go in depth in the understanding of individual motivations that change a random behavior into a daily practice and allows the development of strategies for recovery".

This globalized reality lets us enjoying a "reified" quality of life; creativity is an assumption that rarely is part of the adolescent inventory and this affects them in a stagnant life experience.

\section{Proposals for active and sustainable citizenship.}

We think it is essential, to understand and interpret the footprints adolescents leave us, those living chan- 
ven cambios y transformaciones sociales fugaces, sus formas y estilos de vida, y sus relaciones con las circunstancias que les generan manifestaciones adaptadas. No olvidemos que el fruto dependerá de los adolescentes de hoy y desde esta premisa, hemos considerado de interés la aportación de las siguientes líneas estratégicas:

- Estabilizar las plantillas de los centros educativos e implementar metodologías ricas en el intercambio emocional, que permitan una flexibilización curricular en clave de aprendizaje socioeducativo.

- Hacer visibles los servicios, instituciones y actividades para la participación de los adolescentes en la comunidad, con la intención de incentivar experiencias de ocio y desarrollo prosocial.

- Enriquecer la orientación y calidad de los programas educativos en su vinculación con la formación laboral.

- Promover la autenticidad sobre los estereotipos de belleza y los estilos de vida saludables.

- Integrar desde el contexto escolar, la coherencia en los estilos educativos y trasladarla al plano familiar.

- Incentivar campañas críticas que permitan el cuestionamiento y la concienciación de los adolescentes en relación a los estándares tradicionales que motivan desequilibrios de género.

- Posibilitar en los propios adolescentes la creación de debates en torno a sus incertidumbres, facilitando el logro de alternativas de atención a sus planteamientos futuros.

- Divulgar valores que permitan el acceso a una ciudadanía libre, operativa, solidaria, ecológica, tolerante y responsable, no solamente desde el plano escolar sino a diferentes niveles de socialización: familiar, redes de apoyo social, instituciones culturales, deportivas, solidarias, etc.

- Invitar a instituciones y poderes públicos en la construcción del desarrollo de iniciativas comunitarias que promuevan una ciudadanía sostenible y democrática.

La adolescencia como etapa de búsqueda está plagada de desencuentros $y$, atendiendo a estos, el adolescente los debe reconvertir en aprendizajes con los que configurar su ciudadanía futura. ges and fleeting social transformation, forms and lifestyles, and their relations with the circumstances that generate adapted expressions.

We shouldn't forget that the result will depend on nowadays adolescents and, from this premise, we considered interesting, the contribution of the following strategies:

- To stabilize templates in schools and implement methodologies full of emotional exchanges, that enable a flexible curriculum in a socio learning environment.

- To make visible the services, institutions and activities for the adolescents participation in the community, with the intention of encouraging leisure experiences and prosocial development

- To enrich the orientation and quality of educational programs in its relationship with job training.

- To promote the authenticity of the beauty stereotypes of and healthy lifestyles.

- To integrate from the school context, consistency in educational styles and transfer it to the family level.

- To encourage critical campaigns that allow questioning and awareness of adolescents in relation to traditional standards that cause gender imbalances.

- To enable the teenagers themselves to create debates about their uncertainties, facilitating the development of attention alternatives for their future approaches.

- To spread values that allows the access to a free, operational, supportive, ecological, tolerant and responsible citizenship, not only from the school level but at different levels of socialization: family, social support networks, cultural institutions, sports, charity, etc.

- To invite institutions and public authorities for the construction of the development of community initiatives that promote sustainable and democratic citizenship.

Adolescence as a searching stage is fraught with misunderstandings and, based on these, the adolescent should convert them into learning with which configure their future citizenship. 


\section{REFERENCIAS BIBLIOGRÁFICAS/ BIBLIOGRAPHIC REFERENCES}

Alberdi, I. (1999). La nueva familia española. Madrid: Taurus.

Bohder, F. (1987). Familia y espacio educativo. Madrid: Pro-Logo.

Caride, J. A., Lorenzo, J. J. \& Rodríguez, M.A. (2012). Educar cotidianamente: el tiempo como escenario pedagógico y social en la adolescencia escolarizada. Pedagogía Social. Revista Interunivesitaria, 20, 19-60. doi: 10.7179/psri_2012.20.1

Cieslick, G. \& Pollock, E. (2002). Young People in Risk Society. The Restructuring of Youth Identities and Transitions in Late Modernity, Ashgate: Aldershot.

Claes, M., Lacourse, E., Ercolani, A., Pierro, A., Leone, L. \& Presaghi, F. (2005). Parenting, Peer Orientation, Drug Use, and Antisocial Behavior in Late Adolescence: A Cross-National Study. Journal of Youth and Adolescence, 34, 5, 401-411. doi: 10.1007/s10964-005-7258-8

Cohen, S. (1985). Visions of Social Control: Crime, Punishment and Classification. London: PolicyPress.

Colectivo Lorenzo Luzuriaga (2012). Documento sobre el fracaso escolar en el Estado de las Autonomías. Madrid: Wolters Kluwer.

Dempsey, K. \& Lescott, G. (2013). Complexity and family conflict. Journal of Family Therapy and Cognitive, 6, 3, 303-311.

Espada, J.P., Morales, A. \& Orgilés, M. (2013). Relación entre la edad de debut sexual y el sexo bajo los efectos de las drogas en la adolescencia. Revista española de drogodependencias, 1, 25-35

Feixa, C. (2011). Juventud, espacio propio y cultura digital. Revista Austral de Ciencias Sociales. 20, 95-120. doi: $10.4206 /$ rev.austral.cienc.soc.2011.n20-07

Funes, J. (2009). 9 ideas clave para educar en la adolescencia. Barcelona: Graó Ediciones.

Garrido, V., Stangeland, P. \& Redondo, S. (1999). Principios de Criminología. Valencia: Tirant lo Blanch.

Gil Calvo, E. (2004). Emancipación tardía y estrategia familiar. Revista de Estudios de Juventud, 58, 9-18.

Gil Calvo, E. (2008). Consecuencias de la familia carencial en el niño difícil. Conexiones. Revista de reflexión sociológica de la Universidad de Sao Tomas. 4, 56-67.

He, K., Kramer, E., Houser, R.F., Chomitz, V.R. \& K.A. Hacker (2004): Defining and underst and inghealthy life styles choices for adolescents. Journal of Adolescent Health, 35, 26-33. doi: 10.1016/j.jadohealth.2003.09.004

Herrero, M.N. (2003). Adolescencia, grupo de iguales, consumo de drogas y otras conductas problemáticas. Revista de Estudios de Juventud, 62, 81-91

Hutchinson, S.H. \& Robertson, B.J. (2012). Educación para el Ocio: ha llegado la hora de un nuevo objetivo para una vieja idea. Pedagogía Social. Revista Interuniversitaria, 19, 127-139.

Livingstone, S. (2013). Online risk, harm and vulnerability: reflections on the evidence base for child Internet safety policy, Zer: Revista de Estudios de Comunicación, 35, 13-28.

Lucchini, R. (1999). Niño de la calle: Identidad, sociabilidad, droga. Barcelona: Los libros de la Frontera.

Marín, F. J. \& Olivares, A. (2009). Motivations for the physical and sport activity and their social environment in the secondary students from a public center and a private center in Granada. Retos, 16, 108-110.

McLuhan, M. \& Fiore, Q. (1967).The medium is the message. New York: RandomHouse.

Moral, M.V. (2004). Jóvenes, redes sociales de amistad e identidad psicosocial: la construcción de las identidades juveniles a través del grupo de iguales. Revista galego-portuguesa de psicología e educación: revista de estudios e investigación en psicología y educación, 11, 183-206.

Navarro, J.J. \& Puig, M. (2010). El valor de la educación afectiva con niños en situación de vulnerabilidad acogidos en instituciones de protección; un modelo de trabajo social basado en la cotidianidad. Revista de Servicios Sociales y Política Social, 90, 65-84.

Ovejero, A., Moral, M.V. \& Pastor, J. (1998). La construcción de la conexión entre percepción de la autoimagen física en adolescentes y la identidad psicosocial. Aula Abierta, 71, 145-172.

Puig, M. (2013). Pedagogía de la cotidianeidad en el Centro de Recepción de Monteolivete: 25 años de trabajo con menores. Material no Publicado. 
Rivière, M. (2002). Moda de los jóvenes: un lenguaje adulterado. En Félix Rodríguez (Comp.). Comunicación y cultura juvenil. Barcelona: Ariel. 87-92.

Rubio Gil (Dir.) (2009). Adolescentes y jóvenes en la red: factores de oportunidad. Madrid: Observatorio de la Juventud, INJUVE.

Ruiz, T. (2009). Sociología de la familia. Alicante: Ediciones de la Universidad de Alicante.

Scandroglio, B. \& López, J. S. (2013). La violencia grupal juvenil. Psicología Política, 46, 95-115.

Scheier, L.M., Botvin, G.J. \& E. Baker (1997). Risk and protective factors as predictors of adolescent alcohol involvement and transitions in alcohol use: A prospective analysis, Journal of Studies on Alcohol, 58, 652-667.

Scheler, M. (2000). El formalismo en la ética y la ética material de los valores. Madrid: Caparrós.

Steinberg, K. (2003). Razonamiento moral y la ilógica adolescencia. Santiago: Sarabia.

Tarín, M. \& Navarro, J.J. (2006). Adolescentes en riesgo: casos prácticos y estrategias de intervención socioeducativa. Madrid: CCS.

Taylor, S. J. \& Bogdan, R. (1994). Introducción a los métodos cualitativos de investigación: la búsqueda de significados. Barcelona: Gedisa.

Tonucci, F. (2007). Frato, 40 años con ojos de niño. Barcelona: Octaedro.

Uceda, F.X. Pitarch, M.D. \& Montón, C. (2012). Incidence of supply of public and private educational services in regards with vulnerability and social exclusion: the case of the city of Valencia. Pedagogia $i$ Treball Social, Vol. 2, (2), 25-46.

Valverde, J. (2002). El dialogo terapéutico en exclusión social. Madrid: Narcea.

Vilar, R. (1985). Las raíces sociales en la delincuencia de menores. Revista Poder Judicial, 16. Madrid: Ediciones del Consejo General del Poder Judicial.

\section{Notas}

1 “De los tiempos educativos a los tiempos sociales: la construcción cotidiana de la condición juvenil en una sociedad de redes. Problemáticas específicas y alternativas pedagógico-sociales" (EDU2012-39080-C07-00). Funded under National Plan I + D + i, under a grant from the Spanish Ministry of Economy and Competitiveness and the European Regional Development Fund (FEDER, 2007-2013).

2 Datos derivados del informe realizado por el Colectivo Lorenzo Luzuriaga (2012)

3 Datos obtenidos por el INE, para el curso 2012/2013

4 Data derived from the report by the Collective Lorenzo Luzuriaga (2012)

\section{CÓMO CITAR ESTE ARTÍCULO / HOW TO CITE THE ARTICLE}

Navarro-Pérez , J., Pérez-Cosin, J. \& Perpiñán, S. (2015). El proceso de socialización de los adolescentes: entre la inclusión y el riesgo. Recomendaciones para una ciudadanía sostenible. Pedagogía Social. Revista Interuniversitaria, 25 143-170. doi:10.7179/PSRI_2015.25.7

Fecha de recepción del artículo / received date: 23.VI.2014

Fecha de revisión del artículo / reviewed date: 24 . VI.2014

Fecha de aceptación final / accepted date: 20. X.2014

\section{DIRECCIÓN DE LA AUTORA/ AUTHOR'S ADDRESS}

José-Javier Navarro-Pérez y José-Vicente Pérez-Cosin. Facultad de Ciencias Sociales. Universidad de Valencia. Campus Tarongers. Av. de los Naranjos, 4-B. 46021. Valencia (Spain). Dirección de correo/e-mail: J.Javier.Navarro@uv.es and Jose.V.Perez@uv.es

[ 168 ] JOSÉ-JAVIER NAVARRO-PÉREZ, JOSÉ-VICENTE PÉREZ-COSÍN Y SILVIA PERPIÑÁN SIPS - PEDAGOGIA SOCIAL. REVISTA INTERUNIVERSITARIA [1139-1723 (2015) 25, 143-170] TERCERA ÉPOCA 
Silvia Perpiñán Hinarejos. Department of Modern Languages and Literatures. University of Western Ontario (Canadá). Dirección de correo/e-mail: sperpina@uwo.ca

José-Javier Navarro-Pérez (1975). Trabajador Social, Educador Social y Licenciado en Criminología. Máster en Salud Mental Comunitaria y Máster Oficial y Doctor en Desarrollo Local y Territorio. Imparte docencia en los Grados de Criminologia, Educación Social y Trabajo Social y en el Master de Bienestar Social. Profesor Titular del Departamento de Trabajo Social y Servicios Sociales de la Universitat de València. Co-director del Master de Prevención e Intervención con Adolescentes en Riesgo y Violencia Filio-parental (2a Ed). Ha trabajado durante 13 años en el Equipo Técnico de la Colonia San Vicente Ferrer (Centro de Reeducación de Menores de Valencia dependiente de la Generalitat Valenciana), además ha trabajado como educador social en el mundo de la prevención -medio abierto- y la protección de Menores -centros de acogida- durante 11 años. Autor de diferentes libros y artículos de investigación en revistas nacionales e internacionales indexadas en bases de datos de prestigio: Thompson, Latindex, Redalyc, In-Res, Dice-Cindoc y Scopus. Autor -junto a Manuel Tarín, en 2006- del libro "Adolescentes en Riesgo; casos Prácticos y Estrategias de Intervención Socioeducativa". Madrid: CCS (actualmente en su $4^{\mathrm{a}} \mathrm{Ed}$ ) y en 2010 junto a Pérez Cosin y Uceda Maza, del libro titulado "Propuestas de Intervención Socioeducativa con las Adolescencias". Valencia: Nau LLibres. Ha participado en proyectos trasnacionales de investigación dependientes de convocatorias competitivas. Asimismo presenta estancias de investigación en equipos multidisciplinares de infancia y juventud en América Latina, África y Europa y es Investigador del Instituto Interuniversitario de Desarrollo Local de la Universitat de València (Grupo Seseco), del Instituto de Estudios Pedagógicos y Reeducativos de la FUNLAM (Medellín, Colombia) y está vinculado a redes internacionales por la investigación de la infancia REDidi,, Casiopea...etc.

José-Vicente Pérez-Cosin (1958). Trabajador social, doctor y licenciado en Ciencias Políticas y Sociología, Master en desarrollo local y gerencia de servicios sociales. Profesor titular de trabajo social en la Universitat de València. Su experiencia se centra en el análisis de las políticas públicas, incluida la universidad pública en su última etapa. Actualmente es director del departamento de trabajo social y servicios sociales, en la docencia del título de grado en trabajo social de la Facultad de Ciencias Sociales. Además, dirigir el Máster interuniversitario en gestión y promoción del desarrollo local en su condición de investigador principal del área de cohesión social del Instituto Interuniversitario de Desarrollo Local. Ha dirigido proyectos competitivos de l+D+l europeos y contratos de investigación con las Administraciones Públicas (locales y autonómicas). Es evaluador experto de la Agencia Nacional de Evaluación y Prospectiva y tiene publicados artículos científicos en revistas nacionales e internacionales de impacto, registradas en las instituciones de mayor prestigio como: Thompson, Latindex, Redalyc, In-Res, Dice-Cindoc. En los últimos 5 años, ha formado a dos nuevos doctores y dirige diez proyectos de tesis doctoral, tres de ellos con financiación pública de los programas predoctorales nacionales (FPU) y autonómicos (Val I+D).

Silvia Perpiñán Hinarejos (1978). Doctora en Lingüística Hispánica con especialidad en adquisición y educación en segundas lenguas por la Universidad de Illinois, Urbana-Champaign; Máster en Lingüista, y Licenciada en Filología por la Universidad Autónoma de Barcelona. Profesora de la Universidad de Western Ontario, Canadá, donde imparte clases de lingüística hispánica en la licenciatura de español, y clases de adquisición de lenguas secundarias, mantenimiento de las lenguas de herencia, metodología y estadística aplicadas al estudio de la lingüística experimental en el doctorado de estudios hispánicos y en el Master interdisciplinar de lingüística. Ha trabajado con estudiantes de lenguas extranjeras durante más de 10 años, y estudia tanto los procesos de aprendizaje de segundas lenguas como el mantenimiento y la pérdida de lenguas primeras en generaciones de inmigrantes. Ha publicado varios artículos sobre estos temas en revistas internacionales indexadas en LLBA y MLA, y ha editado dos libros sobre la adquisición de lenguas, el último titulado *The Acquisition of Spanish in Adult and Child Bilingualism, Data from Understudied Lan- 
guage Pairings *que aparecerá en John Benjamins (Amsterdam) a mediados de 2014. Ha presentado en más de 20 congresos internacionales, invitada por universidades como la Universidad de Montréal o la Universidad de California para impartir ponencias sobre sus temas de investigación. Ha obtenido a través de concurso público, becas del gobierno canadiense para llevar a cabo sus investigaciones. Recientemente, su análisis se centra en los procesos lingüísticos propios del bilingüismo y las lenguas en contacto, especialmente en el contacto de lenguas en Cataluña. 